Studia Oecumenica 17 (2017)

DOI: $10.25167 / \mathrm{SOe} / 17 / 2017 / 335-364$

Krystian KaŁUŻA

Wydział Teologiczny UO

\title{
Chrześcijaństwo i religie niechrześcijańskie w myśli Karla Bartha
}

\author{
Christianity and Non-Christian Religions in the Thought of Karl Barth
}

\begin{abstract}
The aim of the article is to present Christianity and non-Christian religions in the thought of Karl Barth. The ideas of the Swiss theologian about religions are characterized by a deep evolution, which allows to single out three basic phases of shaping his thought. In the first phase, present in the first edition of The Letter to the Romans (Der Römerbrief, Zürich 1919), the author allows a view that pagans who are aided by the light of reason may get to cognition of God. Religions in such a view present themselves as meaningful testimony to human rising towards God. This vision is given up in the next phase, in the second edition of The Letter to the Romans (Der Römerbrief, Zürich 1922), and in The Church Dogmatics (Die Kirchliche Dogmatik, 1932-1966). Religions are viewed here as the "unbelief" (Unglaube), an expression of human hubris and an attempt of self-justification. In the third phase of his theological activity Barth revised and slightly moderated his views by stressing universality of the Word of God and the whole work of Creation as possible means of conveying God's truth. In the modern theology of religion the position of Barth is described as Christocentric exclusivism and considered to be overcome. In the last part of the article a critical evaluation of Barth's concept has been performed, showing its strong and weak points.
\end{abstract}

Keywords: Jesus Christ, Christianity, religion, non-Christian religions, revelation, faith, Church.

\section{Streszczenie}

Celem artykułu jest ukazanie chrześcijaństwa i religii niechrześcijańskich w myśli Karla Bartha. Poglądy szwajcarskiego teologa na religie cechuje głęboka ewolucja, pozwalającą wyróżnić trzy zasadnicze fazy kształtowania się jego myśli. W pierwszej fazie, obecnej w pierwszym wydaniu „Listu do Rzymian” (Der Römerbrief, Zürich 1919), autor dopuszcza pogląd, że poganie wspomagani przez światło rozumu mogą dojść do poznania Boga. Przy takim spojrzeniu religie przedstawiają się jako wymowne świadectwa wznoszenia się człowieka ku Bogu. Ta wizja zostaje porzucona w następnej fazie, w drugim wydaniu „Listu do Rzymian” (Der Römerbrief, Zürich 1922) oraz w „Dogmatyce kościelnej” (Die Kirchliche Dogmatik, 1932-1966). Religie jawią się tutaj jak „niewiara” (Unglaube), wyraz pychy człowieka oraz próba samousprawiedliwienia. W trzeciej fazie swej teologicznej 
aktywności Barth zrewidował i nieco złagodził swoje poglądy, podkreślając uniwersalność Słowa Bożego oraz całego dzieła stworzenia jako możliwego nośnika Bożej prawdy. We współczesnej teologii religii stanowisko Bartha określane jest mianem ekskluzywizmu chrystocentrycznego i uważane jest za przezwyciężone. W ostatniej części artykułu dokonano krytycznej oceny koncepcji Bartha, wskazując jej mocne i słabe strony.

Słowa kluczowe: Jezus Chrystus, chrześcijaństwo, religia, religie niechrześcijańskie, objawienie, wiara, Kościół.

W bogatej twórczości naukowej księdza prof. Piotra Jaskóły, któremu dedykowany jest niniejszy artykuł, można znaleźć prace poświęcone szeroko dyskutowanej dziś problematyce teologii religii ${ }^{1}$. Wrażliwość ekumeniczna oraz otwartość na dialog międzyreligijny to niewątpliwie dwie ważne cechy myślenia teologicznego szanownego Jubilata, których nie powinno zabraknąć w dzisiejszym dyskursie naukowym. Trudno bowiem uprawiać rzetelną i społecznie odpowiedzialną teologię w świecie na wskroś przenikniętym wielokulturowością i religijnym pluralizmem. Tak się akurat składa, że to właśnie teologia protestancka, wokół której koncentrują się główne zainteresowania Księdza Profesora, jako pierwsza otwarła się na dialog ze światem, czego wyrazem była m.in. zapoczątkowana w XIX w. teologia liberalna. Jej ostrze stępiła dopiera „teologia dialektyczna" Karla Bartha i Emila Brunnera, której istotnym elementem było obok krytyki teologii naturalnej - przyjęcie stanowiska ekskluzywistycznego w kwestii relacji chrześcijaństwa do religii niechrześcijańskich. Ponieważ poglądy pierwszego z wymienionych teologów wciąż powracają we współczesnych dyskursach teologicznoreligijnych, warto przyjrzeć się im nieco dokładniej. Temu też poświęcony jest niniejszy artykuł. Jego celem jest analiza oraz krytyczna ocena poglądów Bartha na chrześcijaństwo i religie niechrześcijańskie w ich wzajemnej relacji. W ostatniej części przedłożenia zostanie postawione pytanie, czy w myśli szwajcarskiego teologa można znaleźć elementy, które pod pewnymi warunkami wciąż zachowują aktualność dla współczesnej, otwartej na dialog, chrześcijańskiej teologii religii.

${ }^{1}$ Zob. m.in.: P. JASKÓŁA, Chrystus hinduskiego synkretyzmu religijnego, w: P. JASKÓŁA, S. KozA (red.), Chrystus naszym pojednaniem. Prace przygotowane przez Instytut Ekumeniczny KUL dla upamiętnienia działalności naukowo-dydaktycznej Ks. Bpa Prof. Dra hab. Alfonsa Nossola w Katolickim Uniwersytecie Lubelskim, Opole 1997, 229-239; TENŻE, Nauka o Trójcy Świętej wobec wyzwań dialogów międzyreligijnych, w: K. GóżDź, K. Klauza, Cz. RYchlicKi I IN. (red.), Kościót w życiu publicznym, t. II, Lublin 2002, 115-130; TENŻE, Chrześcijańska nauka o Trójcy Świętej a dialogi międzyreligijne, „Studia Oecumenica” 6 (2006), 113-125; TENŻE, Wyjątkowość Jezusa $w$ dobie dialogów międzyreligijnych i procesów globalizacji, w: R. PORADA (red.), Chrystus świattem ekumenii. W Drodze na Trzecie Europejskie Zgromadzenie Ekumeniczne w Sibiu, Opole 2006, 83-91; TENŻE, Misyjny nakaz Chrystusa i tolerancja chrześcijan, w: M. ChosnaCKI, J. Morawa, A.A. NAPIÓRKowsKi (red.), Dialog ekumeniczny a missio Ecclesiae, Kraków 2011, 199-210. 


\section{Uwagi wstępne}

Karl Barth urodził się w 1886 r. w Bazylei (Szwajcaria). Nazywany jest protestanckim Ojcem Kościoła XX w. Mówi się o nim jako teologu, który w okresie po I wojnie światowej jednym uderzeniem zdruzgotał antropocentryczny zrąb protestantyzmu, kultury oraz przyporządkowaną mu, skrajnie wyjałowioną, ewangelicką ortodoksję. Był niewątpliwie najbardziej wpływowym teologiem ewangelicko-reformowanym od czasów Kalwina.

Poglądy Bartha na religie cechuje głęboka ewolucja, pozwalająca wyróżnić trzy zasadnicze fazy kształtowania się jego myśli. W pierwszej fazie, obecnej w pierwszym wydaniu „Listu do Rzymian” (Der Römerbrief, Zürich 1919), autor dopuszcza pogląd, że poganie wspomagani przez światło rozumu mogą dojść do poznania Boga. Przy takim spojrzeniu religie przedstawiają się jako wymowne świadectwa wznoszenia się człowieka ku Bogu. Ta wizja zostaje porzucona w następnej fazie, w drugim wydaniu „Listu do Rzymian” (Der Römerbrief, Zürich 1922), rozwiniętego w sposób harmonijny i systematyczny w „Dogmatyce kościelnej” (Die Kirchliche Dogmatik, 1932-1966), szczególnie w rozdziale zatytułowanym „Objawienie Boga jako zniesienie prawdziwej religii" ${ }^{2}$. Cel, do jakiego na tym etapie twórczości dąży Barth, to położenie kresu próbie samoubóstwienia człowieka, będącej wyrazem jego aspiracji, a jednocześnie najbardziej widoczną oznaką grzeszności. W trzeciej fazie swej teologicznej aktywności Barth zrewidował i nieco złagodził swoje poglądy, podkreślając uniwersalność Słowa Bożego oraz całego dzieła stworzenia jako możliwego nośnika Bożej prawdy. To, czy zmiana ta jest na tyle istotna, by można było użyć wobec niej sformułowania „nowy Barth” (E. Brunner), zwłaszcza w kontekście teologicznej oceny religii niechrześcijańskich, pozostaje kwestią do dyskusji.

\section{Krytyka teologii naturalnej}

Pierwszym dziełem Bartha, które od razu przysporzyło mu sławy, był „List do Rzymian" (1919). Zapoczątkowało ono nowy kierunek w teologii protestanckiej, zwany teologią dialektyczną. Nazwa „teologia dialektyczna” wzięła się z przekonania Bartha, że prawda o Bogu pozwala wyrazić się jedynie za pomocą dialektyki tezy i antytezy, której ostatecznym słowem nie jest jednak - jak w filozofii

\footnotetext{
${ }^{2}$ K. Barth, Die Kirchliche Dogmatik I/2, München 1932, 304-397 (dalej: KD z podaniem numeru strony).
} 
Hegla - synteza, lecz paradoks. Stąd też często występujące określenie teologii dialektycznej jako teologii paradoksu³ .

Teologia dialektyczna Bartha zwraca się - negatywnie - przeciwko „teologii naturalnej" (theologia naturalis) w obu jej ówczesnych kształtach: z jednej strony w wydaniu liberalnego protestantyzmu ${ }^{4}$ (F. Schleiermacher, A. Ritschl, A. von Harnack, E. Troeltsch, A. Schweitzer i in.), który bez reszty koncentrował się na pobożnym, religijnym człowieku (antropocentryzm, psychologizm, historyzm) miast skupiać się na Bogu i Jego objawieniu, jedynym i absolutnym ośrodku wiary; $\mathrm{z}$ drugiej - w postaci rzymskiego katolicyzmu, który związany z neoscholastyką i Soborem Watykańskim I niejako zrównywał Boga i człowieka, roztrząsając takie zagadnienia, jak: współdziałanie człowieka z Bogiem, natury z łaską, rozumu $\mathrm{z}$ wiarą, filozofii z teologią. Od strony pozytywnej teologia dialektyczna nawiązuje do tradycji reformacyjnej, usiłując być konsekwentną teologią Słowa Bożego (Theologie des Wortes Gottes). Jej właściwą intencją jest obrona „boskości Boga”: Bóg jest „całkowicie inny” (totaliter aliter); między Bogiem a światem zionie nieprzekraczalna przepaść; stosunek Boga do świata jest stosunkiem kryzysu (Krisis) i zaprzeczenia (Widerspruch). Boże orędzie zbawienia „nie jest orędziem religijnym, żadną wiadomością i wskazówką o boskości albo przebóstwieniu człowieka, lecz orędziem o Bogu, który jest całkowicie inny, o którym człowiek jako człowiek nigdy nie będzie czegokolwiek wiedzieć albo posiadać i od którego właśnie dlatego otrzymuje zbawienie"5. W konsekwencji człowiek pozostawiony samemu sobie, na mocy sił rozumu naturalnego, nie ma żadnej możliwości poznania Boga. Poznanie takie możliwe jest tylko i wyłącznie dzięki objawieniu, które supranaturalistycznie, jak szrapnel, spada z góry i eksploduje w ludzkiej historii. W takiej perspektywie wszelkie podejmowane przez człowieka próby przybliżenia się do Boga są niczym innym, jak zwykłą iluzją, bluźnierstwem i bałwochwalstwem ${ }^{6}$.

Sprzeciw Bartha wobec teologii liberalnej dotyczy przede wszystkim jej ontologicznego antropocentryzmu i wynikającej zeń koncepcji religijnego a priori, zgodnie z którą człowiek miałby wrodzoną zdolność (potencję) poznania Boga.

${ }^{3}$ A. Nossol, Dialektyczna teologia, w: EK, t. III, 1254. Należy pamiętać, że określenie „teologia dialektyczna" odnosi się nie tylko do Bartha, lecz do całej grupy teologów, którzy przynajmniej w początkowym okresie dzielili jego poglądy na temat radykalnej transcendencji Boga. Ich organem prasowym było założone w 1922 r. czasopismo „Zwischen der Zeit”.

${ }^{4}$ Pośród cech charakterystycznych teologii liberalnej wymienia się m. in.: łączenie wiary z rozumem, kultury z chrześcijaństwem, przyjmowanie religijnego a priori w naturze człowieka, umożliwiającego poznanie Boga, jak również istnienie ogólnego objawienia Bożego (revelatio generalis) oraz objawienia się Boga w naturze, historii i samoświadomości, poprzedzającego objawienie w Jezusie Chrystusie. Zob. H. Grass, Theologischer Liberalismus, w: RGG IV (Tübingen 1960³), 353n; K. Hecker, Liberalismus und liberale Theologie, w: SM III (Freiburg 1969), 227-234.

${ }^{5}$ K. BARTH, Der Römerbrief (1922), Zollikon - Zürich $1967^{10}, 4$.

${ }^{6}$ Por. KD I/2, 308n. 
Właśnie w owym religijnym uposażeniu, predysponującym człowieka do przyjęcia Bożego objawienia i uzdalniającym go do udzielenia odpowiedzi wiary, Barth dostrzega ,istotę" religii ${ }^{7}$. Jej nieprawda polega głównie na tym, iż kwestionuje ona niezasłużony i niedysponowalny charakter relacji Boga do człowieka. Relacja taka może zaistnieć wyłącznie - i to zarówno pod względem teoretyczno-noetycznym, jak i praktycznym (aspekt usprawiedliwienia) - jako konsekwencja inicjatywy samego Boga, który w swoim samoobjawieniu pozostaje zarówno „przedmiotem”, jak i wewnętrzną zasadą Jego poznania. Inaczej mówiąc, nie tylko rzeczywistość, ale także obiektywna i subiektywna możliwość, nie tylko dar, ale również jego przyjęcie podlegają panowaniu Boga; dar stał się rzeczywistością w Chrystusie, zaś jego przyjęcie staje się możliwe w Duchu Świętym. Dlatego człowiek nie tylko poznaje Boga dzięki objawieniu w Chrystusie, ale również poprzez Boga w Duchu Świętym, podobnie jak otrzymuje zbawienie od Boga w Chrystusie i poprzez Boga w Duchu Świętym. W konsekwencji Barth przeciwstawia człowiekowi szukającemu Boga (religia) Boga szukającego człowieka (objawienie).

Przeciwstawiając Boga i świat, łaskę i naturę, objawienie i rozum, Barth występuje nie tylko przeciwko neoprotestanckiej teologii liberalnej, ale także przeciwko typowej (jego zdaniem) dla katolicyzmu formie teologii naturalnej, dla której istnieje oparte na analogia entis poznanie Boga dostępne i zdobywane przez człowieka (dowody na istnienie Boga), i jedynie poszerzane przez objawienie. Dla szwajcarskiego teologa analogia entis jest - według słynnego sformułowania użytego we wstępie do pierwszego tomu jego „Dogmatyki kościelnej” - „wynalazkiem Antychrysta" i jedynie poważnym powodem, aby nie stać się katolikiem $^{8}$. Nie istnieje żadna droga, która wiodłaby od stworzeń do Boga. Tylko Bóg odpowiada na nasze pytanie, ,kim, czym i jaki” jest Bóg (na tym według Bartha polega suwerenność Bożego objawienia). Dlatego teologia jako „słowo o Bogu”

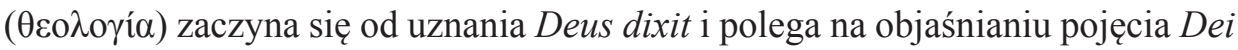
loquentis persona. W tym też tkwi podstawowa trudność, wręcz paradoksalność teologii: „Jako teologowie winniśmy mówić o Bogu. Jesteśmy jednak ludźmi, a jako ludzie o Bogu mówić nie możemy. O jednym i drugim, o naszej powinności i naszej nie-możności, powinniśmy pamiętać i w ten właśnie sposób oddawać Bogu cześć"’.

Barth przyznaje wprawdzie, że człowiek jako stworzenie Boże nie jest z zasady potrzebującym usprawiedliwienia, lecz nosi w sobie potencjalną zdolność do

${ }^{7}$ Por. KD I/2, 344.

${ }^{8} \mathrm{KD} \mathrm{I} / 1$, VIIIn.

${ }^{9}$ K. BARth, Das Wort Gottes als Aufgabe der Theologie, w: K.-J. Kuschel (red.), Lust an der Erkenntnis: Die Theologie des 20. Jahrhunderts. Ein Lesebuch, München 1994, 69. 
podobania się $\mathrm{Bogu}^{10}$ (aspekt praktyczny). Podobnie też nie jest on z natury ślepy na objawienie, lecz została mu udzielona zdolność do poznania Boga ${ }^{11}$ (aspekt noetyczny). Jednak wskutek grzechu, którego rzeczywistość szwajcarski teolog traktuje bardzo poważnie, obydwie ,predyspozycje” (Anlagen) zostały zakwestionowane, skorumpowane i zamienione na swoje przeciwieństwo ${ }^{12}$. Z chwilą gdy człowiek poprzez grzech zatarł w sobie Boże podobieństwo, znajduje się wobec Boga w relacji nieprzekraczalnego dystansu i radykalnego sprzeciwu. Oddzielony od Boga „linią śmierci” człowiek żyje w stanie ontologicznej bez-bożności. Spowodowana grzechem przepaść między Bogiem a człowiekiem jest tak głęboka, że człowiek o własnych siłach nie może nawet jej poznać, a cóż dopiero przekroczyć ${ }^{13}$. Nie istnieje zatem żadna droga prowadząca od człowieka do Boga. Przysługująca człowiekowi możliwość jest wyłącznie możliwością negatywną: Na mocy swojej autonomicznej wolności może on jedynie uchylić się spod panowania Boga i sprzeciwić się Jego słowu, każde zaś odwołanie się do własnych możliwości poznania Boga i podobania się Jemu jest niczym innym, jak pełnym pychy sprzeciwem wobec suwerenności Boga, zaprzeczeniem absolutnego charakteru Jego bycia-Panem, i w tym znaczeniu grzesznym zapoznaniem swojego status corruptionis, co jeszcze bardziej pogrąża go w stanie zawinionej bezbożności. Własne możliwości człowieka zamykają go bezpowrotnie w granicach niewiary - i to właśnie, według Bartha, dzieje się w religiach.

Skonstatujmy raz jeszcze: Sprzeciwiając się teologii naturalnej, Barth pragnie podkreślić, iż ze względu na absolutną transcendencję Boga nie istnieje żadna możliwość poznania Go bez objawienia, czyli bez Bożego Słowa skierowanego do człowieka, a docierającego doń za pośrednictwem Pisma Świętego. Dlatego bosko-ludzka relacja możliwa jest tylko dzięki Bogu, jako wyraz Jego inicjatywy, i za pośrednictwem Ducha Świętego; nie tylko sam fakt objawienia, ale i jego przyjęcie przez człowieka uzależnione są wyłącznie od Boga - są Jego darem, historycznie skonkretyzowanym w osobie i dziele Jezusa Chrystusa. Właśnie objawienie Chrystusowe znosi ową przepaść między Bogiem i człowiekiem, a włączając człowieka w Chrystusa, czyni go uczestnikiem odkupienia. Dopiero na tym tle można zrozumieć, na czym polega teologicznoreligijny ekskluzywizm Bartha, zwany też słusznie ekskluzywizmem chrystocentrycznym. Jego istotę można ująć następująco: Ani rozum, ani doświadczenie, ani historia nie stanowią dróg, które choćby w ograniczonym stopniu dawały przystęp do Boga. Bóg jest Deus absconditus, Bogiem „całkowicie innym”, do którego żadne pojęcie ani żadna

\footnotetext{
${ }^{10}$ Por. KD I/2, 336.

11 Por. KD I/2, 328n.

12 Por. KD I/2, 331, 336.

13 Por. KD I/2, 336.
} 
rzeczywistość ludzka nie są w stanie dotrzeć. Tylko w Chrystusie, w którym odsłania się zarówno rzeczywistość grzechu (krzyż), jak i propozycja zbawienia, napotyka człowiek drogę ku Bogu. Poza Chrystusem jest tylko pycha, zbłąkanie, zamknięcie się w sobie, egzystencjalna pustka i ciemność. Krótko: Extra Christum salus nulla. Kwestia ta stanie się jeszcze bardziej jasna, gdy przyjrzymy się charakterystycznemu dla Bartha pojęciu objawienia.

\section{Prymat Bożego objawienia}

Podstawową kategorią i zarazem centrum organizacyjnym myślenia teologicznego Barta jest objawienie (Offenbarung), które postrzega on jako tożsame z Bogiem: „Objawienie jest Bożą autoprezentacją i samoprzedstawieniem”14. Ma ono z istoty charakter trynitarny i wiąże się z trojaką postacią Słowa Bożego: właściwe i bezpośrednie objawienie dokonuje się w mowie Boga (Deus dixit) przez Jezusa Chrystusa, tj. w objawionym Słowie Bożym; Słowo to jest konkretnie poświadczane za pośrednictwem ludzkiej ograniczoności - jako pamięć o nim w spisanym Słowie Bożym (Pismo Święte) i jako obietnica w słowie przepowiadanym ${ }^{15}$.

O trynitarnym charakterze objawienia decydują trzy elementy strukturalne, odpowiadające trzem Osobom Boskim: Ojciec jako podmiot objawienia; Jezus Chrystus jako obiektywna rzeczywistość i możliwość objawienia; Duch Święty jako subiektywna rzeczywistość i możliwość objawienia. „Nauka o trójjedyności Boga” - pisze Barth - „daje odpowiedź na pytanie o podmiot poświadczonego w Piśmie Świętym objawienia. Odpowiedź tę można streścić następująco: Poświadczone w Piśmie Świętym objawienie jest objawieniem Boga, który jako taki, mianowicie jako Pan, jest Ojcem, od którego ono pochodzi, Synem, które je obiektywnie (dla nas) realizuje, i Duchem Świętym, który je subiektywnie (w nas) urzeczywistnia - Boga, który w owych różnych, nie utożsamiających się ze sobą sposobach bycia i działania pozostaje jednym Bogiem. Bóg jest trwałym podmiotem objawienia”"16. Oznacza to, że Bóg jako Ojciec jest „objawicielem” (Offenbarer), tzn. inicjatorem (źródłem) objawienia, jako Syn - „objawieniem” (Offenbarung), tzn. wydarzeniem (czynem) objawienia, zaś jako Duch Święty - „byciem objawionym" (Offenbarsein), tzn. skutkiem (świadectwem, przekazem) objawienia ${ }^{17}$. W odniesieniu do człowieka jako adresata objawienia należy natomiast po-

\footnotetext{
${ }^{14} \mathrm{KD}$ I/2, 328: Die Offenbarung ist Gottes Selbstdarbietung und Selbstdarstellung.

${ }^{15} \mathrm{Na}$ temat trojakiej postaci Słowa Bożego zob. KD I/1, 89-128.

$16 \mathrm{KD} \mathrm{I} / 2,1$.

17 Por. KD I/1, 311-315.
} 
wiedzieć: Skoro Bóg jest wyłącznym podmiotem objawienia, „nigdy nie może stać się predykatem lub obiektem naszego bycia bądź działania" ". Zatem postawienie „nauki o Trójcy Świętej na szczycie całej dogmatyki” ${ }^{19}$ wyklucza ogólne pojęcie Boga, od którego wychodziła tradycyjna teologia, pytając: Jak poznajemy Boga? Czy Bóg istnieje? Kim jest Bóg? W ramach chrześcijańskiej nauki o Bogu, która zawsze ma do czynienia z konkretnym Bogiem objawienia, teologia naturalna jest - zdaniem Bartha - z zasady niemożliwa: Każda wiedza na temat Boga (teologia) ma swoje źródło w Bogu; poza Nim skazani jesteśmy na ignorancję i błądzenie w ciemnościach ${ }^{20}$. Stąd samoobjawienie (Selbstoffenbarung) Boga jest jednocześnie Jego „autointerpretacją” (Selbstinterpretation) ${ }^{21}$.

Drugi istotny moment objawienia ma charakter ściśle chrystocentryczny: „W wymiarze obiektywnym objawienie Boże to osoba Jezusa Chrystusa"22. Skoro objawienie jest identyczne z Jezusem Chrystusem - konkluduje Barth - to może być ono tylko jedno i jedyne: jest nim jednorazowe i niepowtarzalne wydarzenie Inkarnacji Boga, które swoją unikatową treść otrzymało w życiu, śmierci i zmartwychwstaniu Jezusa Chrystusa. Problematyczność stanowiska Bartha polega na tym, iż dochodzący tutaj wyraźnie do głosu moment historyczny objawienia zostaje przezeń radykalnie ograniczony i zredukowany do mało istotnego minimum: „Objawienie staje się historią; (...) ale nie: historia staje się objawieniem”23. Jest zrozumiałe, iż Barth pragnie w ten sposób uniknąć wszelkich możliwych powiązań z teologią naturalną, którą zdecydowanie odrzuca. Objawienie dociera do nas „pionowo z góry”, tzn. bezpośrednio od absolutnie wolnego Boga, i nie daje się w żaden sposób wydedukować lub wymusić. W odniesieniu do jego „historycznej” rzeczywistości i realności nie może być przeto mowy o „bezpośredniej historycznej poznawalności”. W konsekwencji historia świecka nie ma właściwego sobie znaczenia wobec Boga i Jego zbawczych działań wobec ludzkości. Objawienie dotyka wprawdzie historii, ale w nią nie wchodzi, podobnie jak ,styczna dotyka okręgu”, ale nie wnika do jego wnętrza. Tutaj też tkwi podstawowy punkt krytyki teologii objawienia Bartha, której zarzucono „ewangelicki platonizm”24 (ahistoryzm) oraz

${ }_{18} \mathrm{KD} \mathrm{I} / 2,1$.

${ }^{19} \mathrm{KD} \mathrm{I} / 1,316$.

${ }^{20} \mathrm{KD}$ I/1, 338: So liegt es in dem Wesen dieses Gottes, dass er dem Menschen unenthüllbar ist. Wohl verstanden: gerade in seinem offenbarten Wesen unenthüllbar. Gerade der Deus revelatus (offenbarte Gott) ist der Deus absconditus (verborgene Gott), zu dem hin es keinen Weg und keine Brücke gibt, über den wir kein Wort sagen könnten und zu sagen hätten, wenn er uns nicht eben als der Deus revelatus von sich aus begegnete.

${ }^{21} \mathrm{KD} \mathrm{I} / 1,329$.

${ }^{22} \mathrm{KD} \mathrm{I} / 2,187$.

${ }^{23} \mathrm{KD} \mathrm{I} / 2,64$.

${ }^{24}$ B.E. BenkTson, Christus und die Religion. Der Religionsbegriff bei Barth, Bonhoeffer und Tillich, Stuttgart 1967, 152. 
doketystyczne rozumienie Wcielenia ${ }^{25}$. Skoro bowiem objawienie tylko dotyka historii, pozostając wobec niej rzeczywistością zewnętrzną, to - konsekwentnie - nie ma ono charakteru ściśle inkarnacyjnego; raczej wychodzi na to, „iż objawienie Boże w Jezusie Chrystusie spada niejako prostopadle z góry, bez pośrednictwa człowieczeństwie Jezusa, obok konkretno-historycznej, empirycznie dostępnej postaci Jego posłannictwa. Dokładne, dające się historycznie ustalić okoliczności Jego misji pozostają dla słyszalnego w Nim Słowa bez znaczenia"26. Trudno zatem mówić, iż w Jezusie Chrystusie, Słowie Wcielonym - a więc w historycznie ukonkretnionym fragmencie stworzonej rzeczywistości - Bóg, jako Nieskończony, wszedł w historię świata, poddając się temu, co skończone, kruche i nietrwałe, aby w ten sposób - niejako „od wewnątrz” - przezwyciężyć to wszystko, co uniemożliwia prawdziwą więź (przymierze) między Nim a stworzeniem.

Mimo to Jezus Chrystus jest dla Bartha nie tylko obiektywną rzeczywistością objawienia, ale również jego możliwością, przy czym - odwrotnie niż w ujęciu tradycyjnym - rzeczywistość (faktyczność) poprzedza możliwość: „Obiektywna możliwość Bożego objawienia jest założona w jego obiektywnej rzeczywistości, która ją uzasadnia i czyni dla nas poznawalną" ${ }^{27}$. Stąd porządek poznania musi dostosować się do porządku istnienia: pytanie o fakt poprzedza pytanie o jego zrozumienie $^{28}$. Inaczej mówiąc, samoobjawienie Boga w wydarzeniu Jezusa Chrystusa może być poznane i przyjęte wyłącznie na mocy samego tego faktu, a nie dzięki ludzkim wysiłkom jego zrozumienia. W ten sposób Barth zdaje się relatywizować znaczenie metody historyczno-krytycznej jako użytecznego dla teologii instrumentu poznania tożsamości Mistrza z Nazaretu. Prawda o Jezusie Chrystusie zawarta jest w Nim samym, a nie w empirycznych faktach, dostępnych badaniom historyczno-krytycznym. Tak oto raz jeszcze ujawnia się charakterystyczne dla teologii dialektycznej przeciwstawienie objawienia i historii, łaski i rozumu.

Tajemnica Boga - jej obiektywna rzeczywistość - jest dla nas dostępna tylko i wyłącznie w obiektywnym wydarzeniu Jezusa Chrystusa, w Słowie Bożym, które stało się ciałem. Z drugiej strony - podkreśla Barth - objawienie wciąż pozostaje dla nas cudem i tajemnicą ${ }^{29}$. Również objawienie Chrystusowe nie usuwa tajemnicy Boga, który nie przestaje być Bogiem ukrytym (Deus absconditus). Dlatego objawienie jest zasłonięciem w odsłonięciu ${ }^{30}$. W obiektywnym objawie-

${ }^{25} \mathrm{~W}$ KD I/2, 39, Barth posługuje się dość problematycznym sformułowaniem, mówiąc, iż „człowieczeństwo” Syna Bożego jest , powłoką (Hülle), którą przywdział”. Wobec zarzutu doketyzmu w kontekście swojej nauki o enhipostazie Barth zajął stanowisko w KD IV/2, 53. 292.

${ }^{26}$ J. Werbick, Den Glauben verantworten. Eine Fundamentaltheologie, Freiburg im Br. 20104,

${ }^{27} \mathrm{KD} \mathrm{I} / 2,28$.

${ }^{28}$ Por. KD I/2, 3, 29, 41.

${ }^{29}$ Por. KD I/2, 31.

${ }^{30}$ Por. KD I/2, 45n, 117-125. 
niu, w akcie wolnego wyjścia Boga ku człowiekowi, musi być zachowana Boska suwerenność i wolność łaski ${ }^{31}$. Dla człowieka oznacza to, iż jest on świadkiem przychodzącego doń z zewnątrz i spadającego z góry objawienia, którego nawet nie oczekuje, ale które mu się przydarza jako niezasłużony dar wolnego Boga-Miłości ${ }^{32}$.

Trzeci istotny moment objawienia wiąże się z pytaniem: Co Bóg sprawia w nas, kiedy się objawia? Barth odpowiada: „(...) objawienie polega na tym, że Duch Święty oświeca nas, byśmy mogli poznać Słowo Boże. Wylanie Ducha Świętego jest Bożym objawieniem. W rzeczywistości tego objawienia zawiera się nasza wolność, byśmy mogli stać się dziećmi Bożymi oraz mogli Go w Jego objawieniu poznawać, kochać i wielbić" ${ }^{33}$. Inaczej mówiąc, Duch Święty jest subiektywną (wewnętrzną) zasadą i możliwością objawienia. Bez Jego pomocy, bez Jego światła, poznanie Bożego objawienia nie jest dla nas możliwe. Boga może poznać tylko Bóg; tylko Nieskończony może poznać Nieskończonego. W tym miejscu dotykamy antropologicznego wymiaru objawienia, który - jak słusznie zauważa Barth - jest szczególne podatny na wpływy teologii naturalnej. Chodzi bowiem o pytania: W jaki sposób objawienie staje się dostępne człowiekowi? Jakie warunki muszą być spełnione w samym człowieku jako adresacie objawienia, aby mógł je - właśnie jako Boże objawienie - rozpoznać i przyjąć do swojego życia?

Zdaniem szwajcarskiego teologa, receptywność człowieka względem objawienia Bożego ma swoją podstawę w jego wolności. Jednak wolność ta nie jest właściwością ludzkiej natury, lecz zawsze i za każdym razem aktualnym darem Boga $^{34}$. To zaś oznacza, że również na płaszczyźnie antropologicznej fakt objawienia jest uprzedni w stosunku do jego możliwości; nie istnieją żadne predyspozycje ludzkiej natury, które warunkowałyby możliwość rozpoznania i przyjęcia faktu objawienia. To właśnie Duch Święty jest owym „warunkiem koniecznym”, umożliwiającym poznanie i recepcję Bożego objawienia. „W swojej subiektywnej (tj. wewnątrzludzkiej; KK) rzeczywistości objawienie Boże jest Osobą i dziełem Ducha Świętego, tzn. osobą i dziełem samego Boga" ${ }^{35}$. W ten sposób Barth uznaje reformacyjną ,zasadę braku wolności człowieka względem Boga poza rzeczywistością Ducha Świętego"36. Dzięki temu pragnie on raz jeszcze podkreślić, iż objawienie jest wolnym (suwerennym) aktem łaskawego Boga.

${ }^{31}$ Por. KD I/2, 2-4, 66, 88n.

${ }^{32}$ Por. KD I/2, 78, 113.

${ }^{33} \mathrm{KD} \mathrm{I} / 2,222$.

${ }^{34}$ KD I/2, 224: Diese Freiheit des Menschen kann nur eine von Gott im Akt seiner Offenbarung geschaffene und den Menschen gegebene, sie kann letztlich auch nur Gottes eigene Freiheit sein.

${ }_{35} \mathrm{KD} \mathrm{I} / 2,253 \mathrm{n}$.

${ }^{36} \mathrm{KD} \mathrm{I} / 2,266$. 


\section{Istota religii}

Zanim zapytamy o miejsce religii w systemie Bartha i jej teologiczną ocenę warto zastanowić się, czym według niego religia jest i na czym polega jej istota.

Barth wyróżnia stronę teoretyczną i praktyczną religii. Strona teoretyczna religii to jej zasadnicza treść, a więc rozwijany przez człowieka obraz Boga (bóstwa, bogów), strona praktyczna natomiast to obecny w każdej religii obowiązek czci, czyli kult. Obydwa aspekty religii są ze sobą ściśle powiązane.

Doświadczając w świecie pewnych rzeczywistości i mocy, nad którymi nie da się zapanować i których nie sposób podporządkować własnym potrzebom i interesom, człowiek religijny dochodzi do teoretycznego uznania tego, co boskie (Boga, bogów): „Obraz Boga” - pisze Barth - ,jest zawsze ową postrzeganą i pomyślaną rzeczywistością, w której człowiek uznaje i potwierdza istnienie - poza sobą lub w głębi własnej egzystencji - pewnej właściwej, ostatecznej i decydującej zasady, od której czuje się zależny w swoim istnieniu i która go określa i warunkuje" ${ }^{\prime 37}$. Z tego doświadczenia wyrasta praktyczny obowiązek czci: „Kiedy i gdzie nie wiedziano by o obowiązku człowieka, aby Bogu lub bogom okazywać należną im cześć w postaci konkretnego kultu: poprzez tworzenie obrazów i symboli bóstwa, przez składanie ofiar, przebłagania i modlitwy, poprzez zwyczaje, obrzędy i misteria, przez zakładanie wspólnot i kościołów?" ${ }^{38}$ Podobnie też istnieje w religii zobowiązanie do przestrzegania zasad etycznych, określających właściwe postępowanie człowieka w każdej życiowej sytuacji ${ }^{39}$. Niemniej jednak, niezależnie od słuszności tych zasad, religia jest w każdym przypadku dziełem człowieka, efektem jego własnych poszukiwań i zmagań z rzeczywistością, i dlatego nie ma w niej miejsca na prawdziwą transcendencję $e^{40}$. W tym punkcie Barth pozostaje w zgodzie z podstawową tezą Ludwiga Feuerbacha (1804-1872), że religia jest niczym innym jak produktem antropologicznej projekcji i kompensacji ${ }^{41}$, w których wyraża się sprzeciw czło-

${ }^{37} \mathrm{KD} \mathrm{I} / 2,330$; por. tamże, 306n.

${ }^{38} \mathrm{KD} \mathrm{I} / 2,307$.

39 Por. KD I/2, 337, 344.

${ }^{40}$ R. Bernhardt, Der Absolutheitsanspruch des Christentums. Von der Aufklärung bis zur Pluralistischen Religionstheologie, Gütersloh 1990, 155: Religion ist für Barth ein rein anthropologisch-immanent-säkulares Phänomen; es gehört ganz und gar auf die Seite der Menschen.

${ }^{41}$ K. Barth, Die christliche Dogmatik im Entwurf, t. I: Die Lehre vom Worte Gottes, München 1927, 316: „W wydarzeniu religii jako takim człowiek jest stwórcą Boga, Bóg zaś w wątpliwy sposób jest Bogiem człowieka, predykatem jego własnej, ludzkiej istoty i jego życia". Por. H. KüNG, Existiert Gott? Antwort auf die Gottesfrage der Neuzeit, München 2004³, 568: [F] ̈̈r Barth ist der natürliche Mensch durch und durch Sünder, durchaus vernünftig-verantwortlicher Sünder. Und dieses sündigen Menschen Vernunft ist blind für Gottes Wahrheit! Religiosität, Gotteserkenntnis sind dem Menschen gewiss möglich, das Vermögen dazu besitzt er. Aber er erreicht sein Ziel nicht. Denn der Gott, den diese menschliche Vernunft in der natürlichen Gotteserkenntnis - sei es in der Philosophie oder der Theologie oder in den Religionen der Welt - erkennt, 
wieka naturalnego (tzn. jeszcze nieusprawiedliwionego i nieoświeconego łaską Chrystusa) wobec Boga. Tak oto niewiedza, w której z konieczności tkwi homo religiosus, zostaje podniesiona do rangi istoty religii ${ }^{42}$, a jej perwersja zostaje uznana za jej stan naturalny ${ }^{43}$.

\section{Teologiczna ocena religii}

Przyjęcie powyższych założeń prowadzi Bartha do druzgocącego sądu nad religiami: każda religia - również religia chrześcijańska (!) - jest „tworem człowieka" (Machwerk des Menschen) i w tym sensie niewiarą (Unglaube), bałwochwalstwem (Götzendienst) i „sprawiedliwością z uczynków" (Werkgerechtigkeit $)^{44}$.

Religia jest przede wszystkim ostrym zaprzeczeniem wiary: „Zaczynamy od stwierdzenia: Religia jest niewiarą; religia jest sprawą, powiedzmy to dobitnie: sprawą bezbożnego (gottlosen) człowieka" ${ }^{45}$. Wiara polega na słuchaniu i na akceptacji Bożego daru, religia natomiast na mówieniu i na wysiłku zawładnięcia Bogiem przez człowieka. Dlatego religia jest „fikcją”, a nawet „antybogiem” (Gegengott); jako „niewiara” jest ona dziełem czysto ludzkim, poprzez które człowiek usiłuje dojść do Boga, podczas gdy wiara jest darem Boga, który wyciąga rękę ku człowiekowi. Człowiek jako „religijny z natury” (homo religiosus) poszukuje prawdy o Bogu, ale pragnąc samouświęcenia i samoodkupienia poprzez religię, de facto przeciwstawia religię Bogu i Jego objawieniu. Ostatecznie religie są wyrazem ambicji człowieka, który pragnie dojść do Boga opierając

ist - Feuerbach sieht dies nach Barth durchaus richtig - nichts als Projektion des Menschen; ist das Geschöpf seiner weltanschaulichen Phantasie; ist nicht der eine wahre christliche Gott; ist vielmehr ein Götze, ein Ersatzgott, ein Gegengott. Nein, der Mensch kann den einen wahren Gott nicht erkennen! Außer...? Außer Gott selber gibt sich zu erkennen, außer Gott selber zeigt sich, offenbart sich ihm. Also: keine Gotteserkenntnis des Menschen ohne Gottes Offenbarung! Gott allein hat die Initiative.

42 Por. H. Fries, Absolutheitsanspruch des Christentums, w: LThK², t. I, 74.

${ }^{43}$ Niewątpliwie właściwą intencją Bartha była apologia nadprzyrodzonego charakteru chrześcijaństwa: jako rzeczywistość areligijna, określona wyłącznie przez Boże objawienie, miało ono uniknąć druzgocącego sądu Feuerbacha i innych krytyków religii, przedstawiających religię jako fikcję. Chrześcijaństwo jako nie-religia miałoby nie podlegać tego rodzaju krytyce, której zresztą - jak zdaje się sugerować Barth - trudno nie przyznać pewnych racji. Strategia ta wydaje się jednak mało przekonująca. Wielu widzi w niej tani trik, który zamiast podejmować krytyczną dyskusję z argumentami ateistycznej krytyki ucieka z pola bitwy, by ostatecznie schronić się w bezpiecznej przystani supranaturalizmu. Poza tym, jak słusznie zauważają niektórzy religiolodzy (np. C.H. Ratschow, T. Sundermeier), wszystkie religie, a nie tylko chrześcijaństwo, powołują się na takie czy inne objawienie, w którym upatrują swoją genezę. Jeśli więc chrześcijaństwo chce uzasadnić swoją prawdę, nie wystarczy odwołać się do objawienia Bożego, ale trzeba jeszcze podjąć trud jego uzasadnienia, czego trudno dokonać bez uwzględnienia argumentów rozumowych.

\footnotetext{
44 Por. KD I/2, 327

${ }^{45} \mathrm{KD} \mathrm{I} / 2,327$; por. KD I/2, 328.
} 
się jedynie na własnych siłach, próbując w ten sposób usprawiedliwić się przez własne uczynki, bez pomocy łaski ${ }^{46}$.

W konsekwencji Barth widzi w religii przeciwieństwo objawienia: Religia jest relacją do Boga, którą człowiek pragnie mieć bez objawienia. Dlatego objawienie Boże jest sądem nad religiami, obnażającym ich wewnętrzną nieprawdę i bałwochwalczy charakter. Odsłania ono „niekonieczność wszystkich religii”, ich kontyngentną naturę, czego wyrazem jest wrodzona niemoc człowieka do zrodzenia prawdy - niemoc, którą w równym stopniu potwierdza zarówno jego rozwój religijny, jak i filozoficzny. W tym punkcie Barth pozostaje w całkowitej zgodzie z tradycją reformatorską. Kalwin stwierdzał wprawdzie istnienie w każdym człowieku sensus divinitatis: Quondam sui numinis intelligentiam universis Deus ipse indidit ${ }^{47}$; hominum mentibus indidit illud quod diximus semen religio$n i s^{48}$, jednak to nie wystarcza, chyba że do stworzenia religii fałszywych. Jedynie Pismo Święte daje nam możliwość poznania Boga takim, jakim jest. „Religia naturalna” w żadnym wypadku nie może być „przedsionkiem wiary” ${ }^{49}$. Podobnie argumentuje Barth: Jedynym źródłem prawdziwego poznania Boga jest Boże objawienie $^{50}$, a dokładniej: objawienie Boga w Jezusie Chrystusie. Poza Nim w ogóle nie można mówić o „prawdziwym Bogu”, a jedynie o fałszywych bogach i bóstwach ${ }^{51}$. W kontekście nauki o usprawiedliwieniu, którą szwajcarski teolog ma ciągle na uwadze, oznacza to: Jak nie istnieje dobry człowiek, tak też nie istnieje prawdziwa religia. Gdyby Bóg nie objawił nam się w Jezusie Chrystusie, nadal trwalibyśmy w ciemnościach niewiedzy i w niewoli grzechu. Barth powie wprost: „To, co jest Bogiem dla człowieka naturalnego, i to, co on nazywa swoim Bogiem, jest bożkiem (...) w tym sensie, że «bożek» nie doprowadzi go tak naprawdę do poznania prawdziwego Boga, (...) wprost przeciwnie, jeszcze bardziej oddali go od Niego" 52 .

46 Por. KD I/2, 304: religia jest „ludzką próbą samousprawiedliwienia i samouświęcenia przed stworzonym z własnej upartości i na własną rękę obrazem Boga".

${ }^{47}$ Institutio christianae religionis, I, III, 1.

${ }^{48}$ Tamże, I, V, 1.

49 Por. G. Thils, Problemy teologii religii niechrześcijańskich, Warszawa 1975, 47.

${ }^{50}$ Przekonanie, iż objawienie Boże jest jedynym źródłem poznania Boga oraz że rozum nie jest zdolny do utworzenia adekwatnego (prawdziwego) pojęcia Boga, obecne jest po dziś dzień w niektórych nurtach teologii ewangelickiej. Por. np. E. JüNGEL, Gott als Geheimnis der Welt. Zur Begründung der Theologie des Gekreuzigten im Streit zwischen Theismus und Atheismus, Tübingen 1978, 211: „Rozum jest rozumny jeśli rozumie, że sam z siebie nie jest zdolny do utworzenia pojęcia Boga. Rozum jest rozumny jeśli rozumie, że Bóg w ogóle może być dopiero wtenczas pomyślany jako Bóg, jeśli jest pomyślany jako Bóg objawiający samego siebie”.

${ }^{51} \mathrm{KD} \mathrm{I} / 2,343:(. .$.$) es ist Gottes Offenbarung in Jesus Christus und sie allein, durch die diese$ Charakterisierung der Religion als Götzendienst und Werkgerechtigkeit und damit ihre Entlarvung als Unglaube wirklich vollzogen wird.

${ }^{52} \mathrm{KD} \mathrm{II} / 1,94$. 


\section{Objawienie jako „zniesienie” religii}

Między religią a objawieniem zachodzi zatem przeciwieństwo; nie ma tu żadnej kontynuacji, a jedynie dyskontynuacja, całkowite zerwanie. $\mathrm{Z}$ drugie strony Barth przyznaje: „W swoim objawieniu Bóg jest obecny w świecie ludzkiej religii” ${ }^{33}$. Dlatego można, a nawet należy mówić o człowieczeństwie objawienia: „Zaprzeczenie człowieczeństwu objawienia (Menschlichkeit der Offenbarung) (...) oznaczałoby zaprzeczenie objawieniu jako takiemu"54. Podkreślenie antropologicznego wymiaru objawienia Bożego nie unieważnia jednak podstawowej tezy Bartha, zgodnie z którą religia musi całkowicie podporządkować się objawieniu, a nie odwrotnie, jak chciała tego teologia liberalna. Podporządkowanie religii objawieniu wynika wprost z panowania Boga nad światem: nic nie może sprzeciwić się Jego pierwszeństwu i absolutnej suwerenności.

By ustalić właściwą relację między religią a objawieniem, Barth sięga do słownika filozofii idealistycznej, a konkretnie po słowo Aufhebung. Stąd słynny rozdział 17 KD I/2 nosi znamienny tytuł: Gottes Offenbarung als „, Aufhebung” der Religion. Zgodnie z Heglowskim sposobem myślenia, słowo Aufhebung posiada podwójne znaczenie, które najlepiej oddają dwa inne terminy łacińskie: negatio i elevatio. W odniesieniu do koncepcji Bartha można powiedzieć, że w zależności od tego, jak religia postrzega samą siebie w relacji do objawienia, takiego też znaczenia nabiera słowo Aufhebung. Jeśli człowiek religijny nie poddaje się pod całkowite władanie objawienia, jeśli wierzy, iż polegając na własnych siłach może wznieść się na wyżyny transcendencji i tak ustanowić własną relację do ponad-światowego Boga, wtenczas Aufhebung oznacza po prostu negatio. Objawienie jest wtedy radykalnym sądem Boga nad religią - jej „zniesieniem”, bezkompromisową „negacją”, całkowitym „zakwestionowaniem”. Jeśli natomiast religia postrzega siebie jako wyraz Bożego objawienia, któremu przyznaje absolutne pierwszeństwo, wówczas Aufhebung nabiera pozytywnego znaczenia, którego istotny sens zawiera się w słowie elevatio. Inaczej mówiąc, w poddanej objawieniu religii dochodzi do głosu suwerenna decyzja Boga, który ową religię wybiera i wynosi na wyższy poziom, by uczynić z niej religię prawdziwą. Przy tym elevatio nie oznacza, że Bóg skłania się ku jakiemuś religijnemu a priori w człowieku, które oczyszcza i udoskonala. Przeciwnie, żadne pozytywne nawiązanie do ludzkiej natury i wywiedzionej z niej religii nie wchodzi w rachubę; w naturze człowieka nie ma niczego, na czym mogłoby się wesprzeć objawienie. Stąd postulat całkowitego podporządkowania się religii objawieniu: tylko stamtąd może przyjść do niej prawda. Ostatecznie „zniesienie religii” w sensie eleva-

\footnotetext{
$53 \mathrm{KD} \mathrm{II} / 1,324$.

$54 \mathrm{KD} \mathrm{II} / 1,309$.
} 
tio należy rozumieć $\mathrm{w}$ analogii do chrystologicznej nauki o asumptio carnis ${ }^{55}$. Jedynie w tej perspektywie można powiedzieć: „Zniesienie religii przez objawienie nie musi być rozumiane wyłącznie jako negacja, jako sąd: religia jest niewiarą. Mimo że religia pod ów sąd podpada, może jednak znaleźć się w dobrych rękach objawienia, może być przez nie utrzymana i znaleźć w nim schronienie, może zostać przez nie usprawiedliwiona i - dodajmy od razu: uświęcona" ${ }^{56}$.

Widać stąd, iż Barth traktuje religię jako fenomen teologicznej antropologii, zrównuje ją z człowiekiem stającym w obliczu Boga oraz rozpatruje w horyzoncie napięcia między grzechem a usprawiedliwieniem, hamartologią a soteriologią ${ }^{57}$. Zapośredniczenie obydwu przeciwieństw staje się możliwe dzięki zastosowaniu klasycznego schematu: byt (Sein) - stawanie się (Werden). Podobnie jak człowiek jest grzesznikiem (peccator), a sprawiedliwym (iustus) może jedynie stać się, tak też religia: sama z siebie jest tylko fałszem, bezbożnością i niewiarą, zaś dzięki objawieniu może stać się naczyniem wiary i prawdy. Relacja między religią a objawieniem ma więc charakter dialektyczny, uwarunkowany napięciem między „bytem” a „stawaniem się”; integracja obydwu przeciwieństw możliwa jest tylko dzięki podarowanemu przez Boga simul. W odniesieniu do Bożej prawdy oznacza to: „Żadna religia nie jest prawdziwa” - „Prawdziwą (...) religia może tylko stać się"

\section{Chrześcijaństwo a religie}

W świetle powyższych analiz widać wyraźnie, iż Barth nie miał na celu określania relacji między chrześcijaństwem a religiami niechrześcijańskimi, gdyż w perspektywie objawienia każda religia - również chrześcijaństwo - jest wyrazem ludzkiego sprzeciwu wobec Boga i jako taka godna jest odrzucenia. Nie ma zatem żadnych istotnych różnic między religiami. Wszystkie one są w jednakowym stopniu zwodnicze i fałszywe. Jedyną prawdą jest słowo Boże, poza którym istnieje tylko kłamstwo i nieprawda. Należy przy tym zauważyć, iż Barthowi nie chodzi o historyczną rzeczywistość poszczególnych religii, lecz o ich ocenę teologiczną: wszystkie one stawiają się przed i ponad objawieniem. W konsekwencji relacja chrześcijaństwa do religii niechrześcijańskich, podobnie jak relacja

55 Por. KD I/2, 324.

${ }^{56} \mathrm{KD}$ I/2, 357: Die Aufhebung der Religion durch die Offenbarung braucht nicht bloß zu bedeuten: ihre Negation, nicht bloß das Urteil: Religion ist Unglaube. Die Religion kann in der Offenbarung, obwohl und indem ihr jenes Urteil gilt, wohl aufgehoben, sie kann von ihr gehalten und in ihr geborgen, sie kann durch sie gerechtfertigt und - fügen wir gleich hinzu: geheiligt sein.

57 Por. R. Bernhardt, Der Absolutheitsanspruch des Christentums, 157.

${ }^{58} \mathrm{KD} \mathrm{I} / 2,356$. 
samego objawienia do religii, ma charakter dialektyczny: może ono stać zarówno po stronie świata jako religia i niewiara, jak i po stronie Boga jako wyraz wiary i miejsce usprawiedliwienia.

Konsekwentnie intencją Bartha nie było przeciwstawienie chrześcijaństwa jako „religii absolutnej” (absolute Religion) wszystkim pozostałym religiom, lecz ścisłe odróżnienie wiary od religii. W efekcie jego negatywny sąd nad religiami dotyczy również tego, co w chrześcijaństwie jest „religią”. W momencie bowiem, gdy chrześcijaństwo sprzeciwia się objawieniu, gdy pragnie żyć i nauczać w oparciu o własne siły, a nie dzięki sprawiedliwości Bożej, zrównuje się z innymi religiami, a nawet staje się bardziej grzeszne niż one. Tego rodzaju próby dominacji chrześcijaństwa nad objawieniem miały miejsce w jego historii i nadal stanowią realne zagrożenie. Jednak ta sama religia może zostać usprawiedliwiona przez łaskę, uświęcona i w tym sensie stać się religią prawdziwą. Dzieje się tak wtedy, gdy rodzi się w niej szczere pragnienie grzesznika, by zostać usprawiedliwionym przez Boga i tylko przez Niego (sola gratia). Właśnie to dokonało się w chrześcijaństwie dzięki Jezusowi Chrystusowi i Jego łasce: „Prawdziwa religia jest [podobnie] jak usprawiedliwiony człowiek stworzeniem łaski (Geschöpf der Gnade). Łaska zaś jest Bożym objawieniem"59. Chrześcijaństwo jest więc religią prawdziwą tylko dzięki Bożej łasce, przy czym sformułowanie „dzięki Bożej łasce” znaczy dla Bartha tyle, co „dzięki imieniu «Jezus Chrystus»"“60. Zatem jedynie „w imieniu Jezusa Chrystusa, tzn. w zaistniałym w Jezusie Chrystusie objawieniu i pojednaniu, chrześcijanie są nosicielami prawdziwej religii", i to jedynej prawdziwej religii ${ }^{61}$.

Tak oto dynamika Słowa Bożego, wyrażająca się w dwóch naturach Jezusa Chrystusa, umożliwia związek objawienia z religią, a tym samym uznanie religii za nośnik objawienia. To Chrystus wprowadził chrześcijaństwo we wspólnotę ze swą ludzką naturą, czyniąc je ,aneksem” tej natury, a tym samym dokonując jego usprawiedliwienia. Co więcej, jedyna i ekskluzywna prawda Boża manifestuje się, zdaniem Bartha, wyłącznie w chrześcijaństwie, dlatego pytanie o prawdę nie musi być rozstrzygane w odniesieniu do religii, gdyż odpowiedź na nie została już dana w objawieniu - przed wszelką religią. Dzięki obecnej w chrześcijaństwie rzeczywistości Bożej stoi ono wobec świata religii jako wyróżnione spośród nich i odróżnione od nich, jako jednorazowe, niepowtarzalne i wyłączne ${ }^{62}$.

Czy istnieje zatem religia prawdziwa? Owszem, odpowiada Barth, religia prawdziwa istnieje, podobnie jak istnieje ,usprawiedliwiony grzesznik” (simul

$59 \mathrm{KD} \mathrm{I} / 2,356$.

${ }^{60} \mathrm{KD} \mathrm{I} / 2,3579$.

${ }^{61}$ Szerzej na ten temat zob. KD I/2, 379-397.

${ }^{62}$ Por. I.S. Ledwoń, , ,... i nie ma w żadnym innym zbawienia”. Wyjątkowy charakter chrześcijaństwa w teologii posoborowej, Lublin 2006, 77. 
iustus et peccator). Konkretnie znaczy to: „Religia prawdziwa istnieje jako wydarzenie łaski Bożej w Jezusie Chrystusie"63. Chrześcijaństwo nie jest zatem „religią” w znaczeniu samousprawiedliwienia grzesznika i desperackiej próby „zawładnięcia Bogiem”, lecz jako przyjęte objawienie Boże samo staje się sądem nad religiami. By unaocznić ową krytyczną funkcję chrześcijaństwa wobec religii niechrześcijańskich, Barth posłużył się następującym porównaniem (słynna „metafora Słońca” w KD 17):

To, że Słońce oświeca nie tamtą, ale tę właśnie część Ziemi, oznacza ni mniej, ni więcej jak właśnie ów prosty fakt, że tu panuje dzień, a tam noc, choć tu, jak i tam Ziemia pozostaje ta sama, choć tu, jak i tam nie ma niczego, co z perspektywy samej Ziemi predysponowałoby ją do dnia lub nocy; przeciwnie, bez światła Słońca cała spowita byłaby w ciemnościach. To zatem, że jedna jej część znajduje się w świetle, w żaden sposób nie jest jej zasługą. Właśnie tak i nie inaczej pada światło sprawiedliwości i sądu Bożego na świat religii ludzkości, oświetlając jedną jego część, religię chrześcijańską, dzięki czemu nie pozostaje ona w ciemnościach, ale postępuje w świetle, nie jest religią fałszywą, ale prawdziwą. Choć sama $\mathrm{w}$ sobie jest ona $\mathrm{w}$ nie mniejszym stopniu ludzką religią, a zatem niewiarą, jak wszystkie inne religie (...). Zatem to, dzięki czemu religia chrześcijańska jest religią prawdziwą, nie ma oparcia ani w niej samej, ani w faktach, na które mogliby się powołać jej członkowie, lecz wyłącznie w sprawiedliwości i sądzie Bożym, w obliczu którego stoi zarówno ona sama, jak i inne religie, a który właśnie ją, a nie inne religie, wyróżnił i określił mianem religii prawdziwej ${ }^{64}$.

Tak zdecydowanie negatywna ocena religii niechrześcijańskich może budzić pewne zdziwienie jeśli zważyć na fakt, iż szwajcarski teolog dostrzegał w owych religiach całą paletę postaw i przekonań (prawd wiary, nakazów moralnych, przepisów kultycznych), które stanowią wyraźne paralele w odniesieniu do postaw i przekonań obecnych w chrześcijaństwie ${ }^{65}$. Barth był w oczywisty sposób świadomy faktu, że nie tylko chrześcijaństwo powołuje się na łaskę i objawienie, ale czynią to również inne religie. Jednak według niego chrześcijaństwo różni się od innych religii nie tym, iż przyjmuje postać (Gestalt) religii objawienia i łaski (Offenbarungs- und Gnadenreligion), ale tym, że tylko ono w sposób zasadny i prawomocny wysuwa roszczenie do bycia religią łaski i objawienia. Powodem tego jest fakt, iż rzeczywistość objawienia nie jest bezpośrednio związana z jego formalną strukturą (postacią, kształtem) ${ }^{66}$, a rzeczywistość łaski nie utożsamia

\footnotetext{
${ }^{63} \mathrm{KD} \mathrm{I} / 2,377$.

${ }^{64} \mathrm{KD} \mathrm{I} / 2,388$.

${ }_{65}$ Por. KD I/2, 307.

${ }^{66}$ Por. KD I/2, 360.
} 
z tym, co religioznawstwo zwykło określać mianem „religii łaski" ${ }^{67}$. Skoro tak, to rodzi się pytanie: Co właściwie stanowi o tym, że podnoszone w chrześcijaństwie roszczenia objawieniowo-zbawcze są zasadne, a w innych religiach nie? Według Bartha religijne paralele pokazują wyraźnie, ,że o prawdzie i fałszu w religiach rozsądza tylko jedno. Tym jednym jest Imię Jezus Chrystus"68. Owszem, podkreśla z naciskiem szwajcarski teolog, różnica tkwi „rzeczywiście w całej formalnej prostocie tego Imienia (...)" ${ }^{" 9}$. Konkretnie oznacza to, że prawda chrześcijaństwa nie zawiera się ani w związanych $\mathrm{z}$ owym Imieniem prawdach wiary ${ }^{70}$, ani w specyficznie chrześcijańskim stylu życia, lecz wyłącznie w Imieniu Jezusa Chrystusa, gdyż tylko ono jest oryginalne, jedyne i niepowtarzalne, tylko ono nie znajduje paraleli w innych kontekstach kulturowych, religijnych i moralnych. Barth pisze:

Ani moralność Kazania na Górze (...), ani uzdrowienie niewidomych, sparaliżowanych i opętanych, (...) ani umiłowanie Boga, ani miłość bliźniego, ani cierpienie i śmierć Chrystusa, ani Jego cudowne powstanie z martwych - w zupełności nic z tego wszystkiego, o czym mówi Nowy Testament, nie ma własnej wartości, wewnętrznego ciężaru, abstrakcyjnego znaczenia, pominąwszy fakt, że to właśnie Jezus Chrystus jest podmiotem tego wszystkiego, Imię, w którym to wszystko jest prawdziwe i rzeczywiste $(\ldots)^{71}$.

Wobec powyższego powstaje pytanie: Czy mówiąc o „Imieniu” Barth ma na myśli również osobę, do której Imię to się odnosi? Odpowiedź nie jest łatwa, zwłaszcza że protestancki teolog ma świadomość, iż dostęp do historycznej postaci Jezusa możemy mieć tylko za pośrednictwem świadectwa wiary, w którym jest On wyznawany jako Chrystus, oraz że samo Boże objawienie również dosięga nas wyłącznie za pośrednictwem owego świadectwa, czyli konkretnie w Imieniu Jezusa Chrystusa. W polemice z Paulem Tillichem Barth wyraża nawet przekonanie, iż pytanie o historyczność Jezusa nie jest jakoś szczególnie ważne ${ }^{72}$,

${ }^{67}$ Por. KD I/2, 371.

${ }^{68} \mathrm{KD} \mathrm{I} / 2,376$.

69 Tamże.

70 Tamże: „Zatem nie w bardziej lub mniej wykształconej strukturze właściwej religii łaski, nie w reformatorskiej nauce o grzechu pierworodnym, w nauczaniu o zadośćuczynieniu zastępczym, usprawiedliwieniu wyłącznie z łaski, darze Ducha Świętego i wdzięczności. O wszystkim tym również poganie (...) mogą nauczać, a nawet według tego żyć i przedstawiać się jako Kościół, nie przestając być przez to poganami, całkowicie biednymi i zatraconymi poganami”.

${ }^{71} \mathrm{KD} \mathrm{I} / 2,12$.

${ }^{72}$ K. Barth, Von der Paradoxie des „positiven Paradoxes “. Antworten und Fragen an Paul Tillich, ThB1 2 (1923), 287-296. Przedruk w: J. Clayton (red.), Paul Tillich. Writings in the Philosophy of Religion - Religionsphilosophische Schriften (= Paul Tilllich, Main Works - Hauptwerke, t. IV), Berlin - New York 1987, 106: „Żaden «empiryczny fakt» sam w sobie nie jest objawieniem. Żadne «uznanie» takiego faktu samo w sobie nie jest wiarą. Całe historyczne «życie Jezusa» na przykład, w oderwaniu od świadectwa tych, którzy w owym uniżeniu napotkali majestat, samo 
dając w ten sposób do zrozumienia, iż znaczenie historycznej postaci Mistrza z Nazaretu jest zasadniczo wtórne w stosunku do formalnego Imienia „Jezus Chrystus" wzgl. wyrażonego w tym Imieniu świadectwa wiary. Tak czy inaczej, w obliczu obecnych $\mathrm{w}$ innych religiach chrześcijańskich podobieństw, dotyczących przekonań religijnych, praktyk kultycznych oraz nakazów moralnych, Barth próbuje uzasadnić jedyność chrześcijaństwa jako religii prawdziwej za pomocą czegoś, co nie ma żadnej paraleli w świecie niechrześcijańskim. Tym czymś jest wyłącznie Imię Jezusa Chrystusa - wszystko inne obecne w chrześcijaństwie nie posiada charakteru wyjątkowości i jako takie nie może stanowić kryterium prawdziwości religii. W ten sposób szwajcarski teolog popada w swoisty „formalizm imienia" (Namensformalizmus) ${ }^{73}$, który - przynajmniej na płaszczyźnie religijno-komparatywnej - odmawia jakiegokolwiek znaczenia wszystkiemu, co pod względem kognitywnym, moralnym i duchowym wiąże się z owym Imieniem. Pytanie tylko, czy cena takiego uzasadnienia jedyności chrześcijaństwa nie jest zbyt wysoka? Czy nie mamy tu do czynienia z dramatycznym unieważnieniem treści chrześcijańskiego objawienia, a wraz z nimi samego chrześcijaństwa? Jeśli Barth ma rację, to wszystko, czego Jezus nauczał i czego doświadczył, łącznie z Krzyżem i zmartwychwstaniem, nie ma istotnego znaczenia - liczy się tylko formalna prostota Jego niepowtarzalnego Imienia.

\section{Nowy Barth?}

Ukazany wyżej radykalny ekskluzywizm teologicznoreligijny zdaje się ulec pewnemu złagodzeniu w późniejszej twórczości Bartha, którą cechuje zwrot ku człowiekowi oraz uniwersalizmowi stworzenia. Emil Brunner, wczytując się w tekst KD III/2, używa nawet entuzjastycznego sformułowania „nowy Barth”74. Czy słusznie?

W KD 69,2 raz jeszcze pojawia się metafora światła, jednak tym razem w nieco zmienionej wersji. Również tutaj Jezus Chrystus jest ,jednym, jedynym światłem życia"75; również tu Ziemia nie oświetla samej siebie, lecz cieszy się światłem pochodzącym od Słońca. Jednak - w tym miejscu Barth wychodzi poza KD

w sobie jest niczym innym, jak możliwością, najwyższym prawdopodobieństwem zgorszenia, zaś hipotetyczne «niezaistnienie tego faktu» chciałoby - bez szczególnie istotnego znaczenia - wynieść jeszcze ową możliwość na sam szczyt".

${ }^{73}$ P. Schmidt-Leukel, Gott ohne Grenzen. Eine christliche und pluralistische Theologie der Religionen, Gütersloh 2005, 125.

${ }^{74}$ E. BRUNNER, Der neue Barth. Bemerkungen zu Karl Barths Lehre vom Menschen, ZThK 48 (1951), 89-100.

${ }^{75} \mathrm{KD} \mathrm{IV} / 3 / 1,95$; por. tamze: es gibt kein Licht des Lebens außer und neben dem seinigen, außer und neben dem Licht, das er ist. 
17 - całemu Uniwersum użyczone są światła, które zapalają się w chwili, gdy wschodzi dla nich światło życia ${ }^{76}$. W ten sposób obok wcześniej akcentowanego ekskluzywizmu nowego znaczenia nabiera uniwersalność proroctwa Jezusa Chrystusa, „Jego wszechmoc, dzięki której może On także extra muros Ecclesiae powoływać do życia tego rodzaju prawdziwe słowa" ${ }^{77}$. Tak oto Słońce Prawdy nie pada już tylko na pewien wydzielony fragment Ziemi, lecz sięga swoim nieskończonym światłem po najdalsze krańce całego stworzenia. Stąd oprócz jednego Słowa Bożego (w jego trzech postaciach) istnieją jeszcze inne „słowa”, „prawdy” i „objawienia”78, „światła” i „oświecenia”79, które swoim zasięgiem obejmują cały Wszechświat. Barth odkrywa je przede wszystkim w dwóch obszarach: w formie zwerbalizowanej w świecie ludzkiego profanum oraz w formie niewerbalnej w całym stworzonym Wszechświecie ${ }^{80}$. Warto zaznaczyć, iż przełamując swój dotychczasowy ekskluzywizm w kierunku umiarkowanego inkluzywizmu, szwajcarski teolog wcale nie musiał zmieniać poczynionych wcześniej założeń teologicznych; po prostu dostrzegł, iż objawione w Jezusie Chrystusie i tylko w Nim - panowanie Boga ma zasięg uniwersalny, w związku z czym jego skutki dają się odczuć w całym Uniwersum, a nie tylko w wąskich granicach chrześcijaństwa i Kościoła.

Co w takim razie z religiami? Czy można w nich widzieć nosicieli (przynajmniej potencjalnych) owej czwartej postaci Słowa Bożego? Powyższe rozważania zdają się sugerować, iż tak właśnie jest: w prawdach innych religii należałoby widzieć relatywne odbicie owej jednej i jedynej Bożej Prawdy, która w pełni zajaśniała w Jezusie Chrystusie, Słowie Wcielonym ${ }^{81}$. Wniosek ten wydaje się jednak zbyt pochopny. Należy pamiętać, iż celem Bartha nigdy nie było ukazanie różnych stopni prawdy, obecnych na poziomie prawd świeckich bądź religijnych. Jego pierwszorzędnym zamiarem, towarzyszącym mu do końca twórczości, było ukazanie jakościowej różnicy między słowem Bożym a słowem ludzkim² ${ }^{82}$ W tym punkcie szwajcarski teolog pozostaje niewzruszony. W religiach mamy

${ }^{76} \mathrm{KD}$ IV/3/1, 174: Es ,,aktualisiert (...) ihre Leuchtkraft, so dass sie ihm dienen dürfen und müssen".

${ }^{77} \mathrm{KD} \mathrm{IV} / 3 / 1,153$.

${ }^{78} \mathrm{KD} \mathrm{IV} / 3 / 1,154$.

${ }^{79} \mathrm{KD} \mathrm{IV} / 3 / 1,159$.

${ }^{80}$ Por. R. Bernhardt, Der Absolutheitsanspruch des Christentums, 172.

${ }^{81}$ Już w KD I/2, 925n, Barth przedstawił,,warstwowy model” (Schalenmodell) prawdy religijnej: w jego centrum znajduje się ewangelickie wyznanie wiary, któremu przysługuje funkcja kryteriologiczna i porządkująca; następne warstwy, stopniowo oddalające się od ewangelickiego centrum, to: (a) neoprotestantyzm, (b) rzymski katolicyzm, (c) Kościół wschodni, (d) islam, (e) pozostałe religie niechrześcijańskie. W tym ostatnim obszarze obecne są według Bartha już tylko błędy i fałsz. Por. R. Bernhardt, Der Absolutheitsanspruch des Christentums, 173.

${ }^{82}$ Por. tamże. 
z pewnością do czynienia „,z imponującym tworem (Gebilde) człowieka”\$3, któremu należy się respekt i szacunek, jednak wobec obecnej w nich „fałszywej wiary w fałszywych bogów" ${ }^{94}$ Ewangelia jest bezkompromisowa i nie okazuje żadnego respektu ${ }^{85}$.

W swej późnej twórczości Barth stwarza zatem możliwość, by w ramach przyjętych przez siebie założeń teologiczno-systemowych przyznać religiom niechrześcijańskim elementy dobra, prawdy i świętości, jednak z możliwości tej nie korzysta. Co więcej, w wygłoszonym w 1963 r. wykładzie na temat chrześcijaństwa i religii niechrześcijańskich, w obecności trzystu studentów, z których większość nie była chrześcijanami, szwajcarski teolog bez skrupułów nawiązał do KD 17, oznajmiając: „Chrześcijaństwo nie jest religią”. Stojąc „samotnie pośród wszystkich religii” chodzi „w nim - w odróżnieniu, owszem, w przeciwieństwie do wszystkich religii - nie o dążenie człowieka do Boga, ale o wyjście Boga do człowieka" ${ }^{86}$. Stosunek Bartha do religii niechrześcijańskich dobrze ilustruje też pewne zdarzenie, odnotowane przez cejlońskiego teologa D.T. Nilesa. Wspomina on, iż zapytał kiedyś Bartha, czy kiedykolwiek spotkał Hindusa. Ten odrzekł, że nie. Skąd zatem może wiedzieć - odparł Niles - że hinduizm jest niewiarą? Odpowiedź Bartha: A priori $^{87}$.

\section{Próba krytycznej oceny}

W teologii religii stanowisko Bartha funguje jako modelowy przykład chrystocentrycznego ekskluzywizmu, kwestionującego jakąkolwiek wartość religii niechrześcijańskich: są one niczym innym, jak godnym pożałowania wyrazem niewiary, pychy i chęci samousprawiedliwienia człowieka (grzesznika) przed Bogiem. Przy tym Barthowi nie chodzi o rzeczywistość historyczną religii, lecz o ich ocenę teologiczną: wszystkie one stawiają się przed i ponad objawieniem, i w tym sensie są wyrazem sprzeciwu wobec Boga i Jego zbawczej łaski. Sąd ten dotyczy również chrześcijaństwa, o ile sytuuje się ono w relacji grzesznego „nie” wobec objawienia, jeśli pragnie żyć i nauczać na mocy własnej siły i własnych możliwości, świadomie odsuwając się od usprawiedliwiającej łaski Bożej. Żadna religia nie jest sama z siebie prawdziwa. Jedyną prawdą jest słowo Boże, poza

${ }^{83} \mathrm{KD} \mathrm{IV} / 3 / 2,1003$.

${ }^{84}$ Tamże.

${ }^{85}$ Por. KD IV/3, 421, 923n, 1002; KD IV/2 § 77.

${ }^{86}$ K. Barth, Das Christentum und die Religionen, JK 24 (1963), 436-438; cyt. za: R. BerNHARDT, Der Absolutheitsanspruch des Christentums, 173.

${ }^{87}$ D.T. NILES, Karl Barth - A personal Memory, „The South East Asia Journal of Theology” 11 (1969), 10n. 
którym istnieje tylko fałsz i zakłamanie. Chrześcijaństwo może jednak stać się religią prawdziwą, jeśli podda się usprawiedliwiającej łasce Bożej. Myślenie to ma swoje źródło w protestanckiej nauce o usprawiedliwieniu, w której centrum znajduje się odnoszone do człowieka sformułowanie reformatorów: simul iustus et peccator. Podobnie jak człowiek jest grzeszny, a usprawiedliwiony staje się dzięki Bożej łasce, tak samo religia sama z siebie jest „niewiarą” (Unglaube), zaś dzięki łasce Bóg może ją usprawiedliwić, tzn. uczynić naczyniem prawdziwej wiary. Nie znaczy to, że w akcie usprawiedliwienia istota religii ulega przemianie. Zgodnie z logiką reformatorskiego simul zostaje ona raczej umieszczona w polu dialektycznego napięcia między dwoma biegunami, którymi są Bóg i objawienie z jednej strony oraz świat i religie z drugiej. Dotyczy to zwłaszcza chrześcijaństwa: może ono stać zarówno po stronie świata religii jako „niewiara”, jak i po stronie Boga jako religia prawdziwa. Tym samym Barth nie postrzega religii jako wrogich chrześcijaństwu, lecz podkreśla jedynie, iż tylko wiara w Jezusa Chrystusa przynosi usprawiedliwienie i zbawienie. Mówiąc krótko: Extra Christum nulla salus.

Taka wizja chrześcijaństwa w relacji do objawienia i religii niechrześcijańskich ma niewątpliwie swoje mocne strony. Przede wszystkim zwraca ona uwagę na konieczność podporządkowania teologii objawieniu i Biblii, będących jej zasadniczą normą i podstawowym punktem odniesienia. Emblematycznym przykładem oderwania teologii od jej źródeł biblijnych jest rozwijana od połowy XX w. pluralistyczna teologia religii (J. Hick, P. Knitter, R. Panikkar, P. Schmidt-Leukel i in.), zrównująca chrześcijaństwo pod względem objawieniowo-zbawczym z innymi religiami (zakwestionowanie wyjątkowego charakteru chrześcijaństwa). Dochodzący w niej do głosu postulat uprawiania „teologii globalnej”, tzn. ponadreligijnej i ponadwyznaniowej, oparty jest na przekonaniu, iż punktem wyjścia refleksji teologicznoreligijnej winny być pewne tezy filozoficzne (rzekomo gwarantujące obiektywność i neutralność badań religiologicznych), do których następnie dopasowywane są dane biblijne. $Z$ punktu widzenia metodologii teologii trzeba jednak od razu zastrzec, iż taki sposób postępowania sprzeczny jest z samą naturą teologii, którą - zgodnie z zaleceniem św. Tomasza z Akwinu - należy rozumieć jako refleksję nad całością rzeczywistości sub ratione Dei ${ }^{88}$. Słusznie zatem Barth podkreśla trzy elementy, które winny służyć jako niekwestionowany fundament chrześcijańskiej teologii: obrona boskości Boga, zakorzenienie w objawieniu (urzeczywistnionym w Jezusie Chrystusie i utrwalonym w Piśmie Świętym) oraz oparcie na wierze, bez której nie może być mowy o teologii jako nauce wiary ${ }^{89}$.

88 Tomasz z Akwinu, STh I q. 1 a. 1.

${ }^{89}$ G. Kraus, Gotteserkenntnis ohne Offenbarung und Glaube? Natürliche Theologie als ökumenisches Problem, Paderborn 1986, 90. 
Przy tym wszystkim nie sposób jednak pominąć słabych i kontrowersyjnych punktów teologii Bartha, które doprowadziły go do skrajnie negatywnej oceny religii niechrześcijańskich. Można je sprowadzić do trzech zasadniczych kwestii: formalnego punktu wyjścia jego teologii, zaproponowanej koncepcji objawienia oraz przyjętego a priori pojęcia religii ${ }^{90}$.

Decydujący wpływ na Barthowską koncepcję objawienia i religii miała bez wątpienia jego kontrowersja $\mathrm{z}$ dziewiętnastowiecznym neoprotestantyzmem ${ }^{91}$. Szwajcarski teolog słusznie krytykował przesadny antropocentryzm tego nurtu w tym psychologiczne uzasadnienie wiary u F.D.E. Schleiermachera, oświeceniową redukcję religii i wiary do naturalnej religii rozumu i etyki (I. Kant i teologia liberalna) oraz ewolucjonistyczne relatywizowanie chrześcijaństwa w szkole religijnohistorycznej (J. Weiß, E. Troeltsch, W. Wrede i in.). Jednak z drugiej strony nie da się zaprzeczyć, iż Barth spoglądał na neoprotestantyzm przez ciemne okulary swoich osobistych uprzedzeń i antypatii, dostrzegając w nim tylko to, co negatywne i godne odrzucenia, popadając w ten sposób w jego przeciwieństwo, tj. w jednostronny teocentryzm ${ }^{92}$. Rodzą się zatem pytania: Czy zamiast bezkompromisowej walki nie należało raczej podjąć i krytycznie rozwinąć słusznej skądinąd intuicji teologii liberalnej, wskazującej na antropologiczny punkt wyjścia refleksji teologicznej? Dlaczego nie można było od razu zacząć od „człowieczeństwa objawienia”, nie umniejszając „boskości Boga” i suwerenności Jego zbawczych działań? Jak można w ogóle mówić o bezpośrednim wtargnięciu objawienia w dzieje świata i człowieka, bez uwzględnienia zasadniczej (ontologicznej i psychologicznej) otwartości tego ostatniego na jego przyjęcie i to w granicach autentycznej, choć dotkniętej grzechem ludzkiej wolności? Dziś wydaje się jasne, że nie da się mówić o objawieniu Bożym, bez uwzględnienia historycznej, kulturowej i egzystencjalnej sytuacji człowieka ${ }^{93}$.

90 Por. tamże, 90-95.

${ }^{91}$ Barth zajął się gruntownie neoprotestantyzmem w serii wykładów wygłoszonych w latach 1932-1933. Kilka lat później zostały one opublikowane pod wspólnym tytułem: K. BARTH, Die protestantische Theologie im 19. Jahrhundert, Zürich 1947.

92 Por. G. Kraus, Gotteserkenntnis ohne Offenbarung und Glaube?, 91.

${ }_{93}$ Por. H.U. von Balthasar, Gott redet als Mensch, w: Tenże, Verbum caro, Einsiedeln 1960, 85: „Objawienie nigdy nie spada bezpośrednio z nieba, aby oznajmić człowiekowi z zewnątrz i z góry ponadświatowe tajemnice; Bóg przemawia do człowieka z pośrodku świata, wychodząc od jego osobistych doświadczeń, sięgając tak dalece w głąb swojego stworzenia", iż można powiedzieć, że objawienie jest z istoty „Boską kenozą”, powierzeniem się Boga ludzkiemu pośrednictwu; jest ono zapoczątkowanym ,już w słowie Starego Testamentu" i dopełnionym we wcieleniu Logosu ucieleśnieniem Słowa (Fleischwerdung des Wortes); G. KRAus, Gotteserkenntnis ohne Offenbarung und Glaube?, 92n: „Ogromna zasługa Bartha polega na tym, iż na nowo ukazał on centralne znaczenie objawienia dla wiary chrześcijańskiej. Jednak rozwijając systematycznie solidną teologię objawienia, uległ pewnemu zawężeniu, które krytyka scharakteryzowała jako objawieniowy pozytywizm (Offenbarungspositivismus)”. Pozytywizm ten „uwidacznia się w wyjściu Bartha bezpośrednio od czystego faktu objawienia, świadomie wykluczając w ten sposób jakiekolwiek oddolne uzasadnienie [tegoż faktu - K.K.] (a przez to każdą formę teologii naturalnej)". Czy jednak „objawienie nie staje się przez to czymś zupełnie obcym dla człowieka? (...) Czy uzasadnienie 
Bardziej dokładna analiza twórczości Bartha pozwala dostrzec jeszcze inne, o wiele głębsze źródła jego myślenia, mianowicie teologię reformatorów oraz filozofię idealistyczną, których istotnym elementem jest przekonanie, iż między Bogiem a człowiekiem istnieje nieprzekraczalny dystans. „Bóg jest Bogiem”, powiada Barth, a „świat jest światem"94. Skoro zaś człowiek żyje w świecie i w pewnym sensie jest jego cząstką, to między nim a Bogiem musi zachodzić „nieskończona różnica jakościowa”"95. Obrona boskości Boga, którą szwajcarski teolog stawia sobie jako cel w KD I/1 i I/2, oparta jest na dwóch założeniach tradycji reformatorskiej, które również mają za zadanie uwypuklić nieprzekraczalny dystans między Bogiem a człowiekiem. Chodzi o aksjomat Finitum non est capax infiniti ${ }^{96}$ oraz o teologumen Extra Calvinisticum ${ }^{97}$. Łatwo zauważyć, iż w dalszej perspektywie Barthowskie ujęcie relacji Bóg - człowiek osadzone jest w schemacie platońsko-idealistycznym, zgodnie z którym między tym, co boskie, a tym, co ludzkie, zachodzi chōrismós - dychotomiczne (wzgl. dualistyczne) „albo - albo”, oddzielające i zamykające Boga i człowieka w dwóch różnych światach, między którymi nie zachodzi żadna wewnętrzna relacja ${ }^{98}$. Czy jednak takie ujęcie relacji Bóg - świat pozostaje w zgodzie z opartą na Piśmie Świętym chrześcijańską wizją stworzenia? Czyż Bóg nie jest Bogiem transcendentnym i zarazem immanentnym? Jak zauważa Jürgen Moltmann: „,... przez swego kosmicznego Ducha, Bóg Stwórca nieba i ziemi jest obecny w każdym stworzeniu i w braterstwie stworzeń, jakie jest ich udziałem. Deus penetrat praesentia sua totum uniwersum"99.

możliwości przyjęcia objawienia przez odwołanie się do zdziałanego [bezpośrednio - K.K.] przez Ducha Świętego skoku nie jest czasem konstrukcją, która bezpodstawnie wyklucza jakąkolwiek formę ludzkiego współdziałania?”

${ }^{94}$ K. BARTH, Der Römerbrief (1922), 54, 65. To przekonanie stanowi dla Bartha jedyne „założenie, z jakim przystępuje on do analizy tekstu św. Pawła“ (por. tamże, XIV).

${ }_{95}$ Tamże, 14, 182, 315, 341, 390.

96 Por. B. E. BenkTson, Christus und die Religion. Der Offenbarungsbegriff bei Barth, Bonhoeffer und Tillich, 189-191; P. EICHER, Offenbarung. Prinzip neuzeitlicher Theologie, München $1977,234-236$.

${ }^{97} \mathrm{Na}$ temat zasady Extra Calvinisticum u Bartha zob. W.D. MARSCH, ,, Gerechtigkeit im Tal des Todes". Christlicher Glaube und politische Vernunft im Denken Karl Barths, w: W. DanTINe, K. LÜTHI (red.), Theologie zwischen Gestern und Morgen, München 1968, 184n.

${ }_{98} \mathrm{Na}$ temat elementów platońsko-idealistycznych w myśli Bartha zob. H.U. vON BALTHASAR, Karl Barth. Darstellung und Deutung seiner Theologie, Köln 1962², 210n, 229-259.

99 J. Moltmann, Bóg w stworzeniu, thum. Z. Danielewicz, Kraków 1995, 54; por. P. JASKÓŁA, Ku jedności w Chrystusie. Wybrane zagadnienia z problematyki ekumenicznej i dogmatycznej, Opole 2016, 14n: „Transcendencja Boga zakłada Jego immanencję (...), gdyż wskazuje na zależność od Boga rzeczy stworzonych. Przewyższając i przekraczając rzeczywistość tego świata, Bóg nie jest obok świata czy poza nim. On jest w nim obecny, przenika go i ogarnia, rządzi wszystkim. Możemy go spotkać w zdarzeniach zwykłych i niezwykłych. «W Nim żyjemy, poruszamy się i jesteśmy» (Dz 17,28). (...) Immanencji tej nie można pojmować antropomorficznie, gdyż nie jest ona immanencją w sensie przestrzennym, a więc czymś na wzór przebywania czegoś w czymś. Immanencja Boga współdziała z naturalną przyczynowością stworzeń, zwłaszcza z istotami rozumnymi”. 
Powodem do krytyki jest także ukute przez Bartha pojęcie religii, któremu zarzuca się arbitralność i abstrakcyjność ${ }^{100}$. Jego podstawowa słabość polega na zupełnym oderwaniu od tego, co religie i ich wyznawcy sami mówią o sobie, oraz na pomijaniu danych empirycznych, dostarczanych przez poszczególne nauki religioznawcze (zwłaszcza przez historię i fenomenologię religii) ${ }^{101}$. Z punktu widzenia współczesnej teologii religii sprzeciw budzi przede wszystkim uparcie podtrzymywane przez Bartha separowanie religii od objawienia, a w konsekwencji od zbawienia. Stąd jego zdecydowanie negatywna ocena nie tylko religii niechrześcijańskich, ale także samego chrześcijaństwa, o ile staje ono po stronie religii i usiłuje być religią. Warto wspomnieć, iż w czasie, kiedy Barth tworzył swoją teologię dialektyczną, teologia katolicka prezentowała podobne stanowisko. Praktycznie do Soboru Watykańskiego II Kościół w swoim nauczaniu traktował religie niechrześcijańskie jako naturalne, a przez to fałszywe. Pius XI w encyklice Mortalium animos (1928) stwierdził, że „żadna religia nie może być prawdziwa poza tą, która opiera się na objawionym słowie Bożym”, tj. chrześcijaństwem ${ }^{102}$. Współczesna teologia katolicka zrywa z takim patrzeniem na religie niechrześcijańskie. Jeśli bowiem przez religię rozumieć przeżywany w danej wspólnocie realny związek człowieka z Bogiem (Transcendencją, Absolutem), wyrażający się w kulcie, wierzeniach i postępowaniu moralnym, to tak rozumiana religia musi mieć swoje źródło w objawieniowo-zbawczej inicjatywie Boga. Jak zauważa Heinrich Fries: „Religia jest możliwa i rzeczywista, ponieważ Bóg objawił się człowiekowi, uczynił się rozpoznawalny w stworzeniu, w swoich dziełach"103. Bez objawienia nie ma więc religii, i odwrotnie: tam gdzie jest objawienie, tam możliwa jest również religia ${ }^{104}$. Przy tym przez objawienie rozumie się tutaj takie działanie Boga, poprzez które ujawnia On człowiekowi swe istnienie i swą naturę, a także zaprasza go do wspólnoty życia (zbawienia) ${ }^{105}$. Kwestionowanie nadprzyrodzonej genezy religii niechrześcijańskich, jak to czyni Barth i inni ekskluzywiści, stawia de facto ich wyznawców na jednej płasz-

100 Por. G. Kraus, Gotteserkenntnis ohne Offenbarung und Glaube?, 94.

${ }^{101}$ Nie znaczy to, iż Barth nie dysponował wiedzą religioznawczą; owszem, wiedzę taką posiadał, ale nie miała ona dla niego żadnego znaczenia gdy idzie o teologiczną ocenę religii niechrześcijańskich.

102 Cyt. za: A. Bronk, Nauka wobec religii, Lublin 1996, 103.

${ }^{103}$ H. Fries, Das Christentum und die Religionen der Welt, w: K. Forster (red.), Das Christentum und die Weltreligionen, Würzburg 1965, 22.

104 J. Hessen, Der Absolutheitsanspruch des Christentums. Eine religionsphilosophische Untersuchung, München - Basel 1963, 28n: „Tam, gdzie jest prawdziwa religia, tam też jest objawienie (w najszerszym tego słowa znaczeniu). (...) Jeśli mówi się o religii pozachrześcijańskiej, to mówi się implicite o pozachrześcijańskim objawieniu. Przyjęcie istnienia religii poza chrześcijaństwem przy jednoczesnym zakwestionowaniu objawienia ma swoje źródło w zapoznaniu istoty religijnego doświadczenia lub religijnego przeżycia wartości”.

105 Por. M. Rusecki, Objawienie Boże podstawa religii, w: G. DzIEwUlski (red.), Teologia religii. Chrześcijański punkt widzenia, Łódź - Kraków 2007, 177. 
czyźnie z ateistami i agnostykami, co niewątpliwie jest dla nich krzywdzące i niesprawiedliwe.

Trudno wreszcie zgodzić się ze sposobem, w jaki Barth uzasadnia wyjątkowość chrześcijaństwa. Jak widzieliśmy, według szwajcarskiego teologa chrześcijaństwo zasługuje na uznanie i szacunek nie dlatego, że obecne są w nim elementy dobra, prawdy i świętości, ale dlatego, że odnosi się ono do Imienia Jezusa Chrystusa. Jedynie w „formalnej prostocie” tego „Imienia” leży jego wartość; jedynie w tym „Imieniu” jest łaska i zbawienie. Pytanie tylko, skąd o tym wiadomo? Czy sam formalizm imienia wystarcza, by uzasadnić jedyność i uniwersalność zbawczego pośrednictwa Chrystusa? Poza tym, jeśli liczą się tylko imię oraz osoba Jezusa Chrystusa, ich teologiczna interpretacja (dogmat) pozostaje natomiast sprawą drugorzędną - a to właśnie wydaje się twierdzić Barth -, to dlaczego nie zgodzić się np. z buddyjskim rozumieniem Jezusa jako Bodhisattwy lub z neohinduistyczną interpretacją Jego osoby jako Awatara? Czyż w obydwu przypadkach nie mamy do czynienia ze szczerą próbą ukazania zbawczego znaczenia Jezusa Chrystusa, tyle że w innym kontekście kulturowo-religijnym? ${ }^{106}$ Poza tym Barth zdaje się popadać w tautologię twierdząc, że mimo licznych paraleli, jakie znajdujemy w wierze i w życiu niechrześcijan, jedynie chrześcijaństwo jest prawdziwe, gdyż tylko w nim obecne jest wyraźne odniesienie do Imienia Jezus. Bez dalszych uzasadnień znaczy to po prostu, że tylko chrześcijaństwo jest prawdziwe, bo tylko w nim jest prawda. Co ciekawe, również tego rodzaju roszczenie do wyjątkowości nie pozostaje bez analogii w świecie niechrześcijańskim. Jak zauważył Wilfred Cantwell Smith: „Roszczenie do wyjątkowości nie jest wyjątkowe”"107.

Warto w tym miejscu nadmienić, iż z punktu widzenia teologii katolickiej dość dziwnie brzmi teza Bartha, iż chrześcijaństwo, podobnie jak inne religie, samo w sobie nie jest prawdziwe, ale może stać się religią prawdziwą, jeśli podda się usprawiedliwiającej łasce Bożej. Jeśli pod pojęciem chrześcijaństwa będziemy rozumieć Kościół, to powstaje pytanie, czy chrześcijaństwo jako Kościół jest w ogóle do pomyślenia w oderwaniu od Boga i Chrystusa. Nie ma wątpliwości co do tego, iż pojedynczy chrześcijanie mogą sprzeciwić się Chrystusowi, zignorować Ewangelię i tym samym znaleźć się poza orbitą zbawienia. Jednak Kościół jako całość, jako prawdziwe „Ciało Chrystusa”, nigdy nie może znaleźć się poza Chrystusem i Jego zbawczą łaską. Ponadto twierdzenie Bartha, iż chrześcijaństwo może stanąć zarówno po stronie religii, jak i po stronie objawienia, sugeruje, iż nie ma ono objawieniowej genezy, w związku z czym jego więź z Bogiem i Chrystusem może być jedynie akcydentalna, a nie ontyczna (koniecznościowa).

106 Por. P. Schmidt-Leukel, Theologie der Religionen. Probleme, Optionen, Argumente, Frankfurt am M. 1997, 142.

107 W.C. SMith, Idolatry: In Comparative Perspective, w: J. Hick, P. KNITTER (red.), The Myth of Christian Uniqueness, Maryknoll 1987, 64. 
Trudno zgodzić się z taką tezą. Należałoby wtenczas przyjąć, iż chrześcijaństwo jest $\mathrm{w}$ istocie tworem czysto ludzkim, zaś jego nadprzyrodzony charakter zasadza się wyłącznie na arbitralnej decyzji Boga, który w akcie usprawiedliwienia niejako z zewnątrz uświęca je i podnosi na nowy, nadprzyrodzony poziom egzystencji. Taki też obraz zdaje się sugerować przytoczona wyżej „metafora Słońca” (KD 17). Czy i jak dalece można interpretować ją w kluczu eklezjologicznym, musi tu pozostać kwestią otwartą. Tak czy inaczej, chrześcijaństwo w ujęciu Bartha samo w sobie nie ma żadnej wartości; jego prawda i jego świętość pochodzą wprost od Boga, który wybrał je, uświęcił i uczynił swoją własnością.

Czy wobec powyższego ekskluzywizm Bartha może mieć jeszcze jakiekolwiek znaczenie dla współczesnej teologii religii? Wydaje się, że co najmniej dwie kwestie zasługują na pozytywną uwagę. Pierwsza dotyczy pojęcia absolutności chrześcijaństwa, druga - zbawczego charakteru religii niechrześcijańskich.

Pojęcie „absolutność chrześcijaństwa” (E. Troeltsch) wywodzi się z idealizmu niemieckiego (G.W.F. Hegel mówił o ,absolutnej religii”) i sugeruje, iż chrześcijaństwo stanowi najwyższy, w pełni doskonały i nieprzekraczalny stopień rozwoju wszystkich religii, w związku z czym inne religie znajdują w nim swoje wypełnienie i ostateczny kres ${ }^{108}$. Ponieważ chrześcijaństwo dysponuje pełnią Bożej prawdy, jest one jedyne, wyjątkowe i niepowtarzalne (ekskluzywizm). Barth nie kwestionuje uprzywilejowanej pozycji chrześcijaństwa pośród religii, podkreśla jednak, iż pozycja ta nie wynika z jego natury jako religii absolutnej, lecz jest dziełem Bożej łaski. Objawienie Boże czyni wprawdzie chrześcijaństwo religią prawdziwą, jednak nie daje mu tego przywileju na własność, tzn. nie pozwala mu zidentyfikować się z obecną w nim prawdą i na tej podstawie wysuwać roszczenie do absolutności dla siebie samego. Jakkolwiek brzmi to paradoksalnie, absolutność chrześcijaństwa nie jest absolutnością ,absolutną”, tj. konieczną, bezwzględną, nieuwarunkowaną, lecz absolutnością względną, uwarunkowaną przez objawienie, które jedno tylko ma charakter ściśle absolutny. Dlatego w podarowanej w Chrystusie absolutności tkwi nie tylko godność i wielkość chrześcijaństwa, ale i jego kryzys. Absolutność w sensie ścisłym można przyznać wyłącznie objawieniu Chrystusowemu, chrześcijaństwu zaś co najwyżej wtórnie, jako rzeczywistości, ku której zwraca się Bóg ze swoją prawdą i łaską. Stąd Barth wprowadza ścisłe rozróżnienie między religijną samoświadomością historycznego chrześcijaństwa z jednej strony a podarowaną przez Boga prawdą objawienia wzgl. samym objawieniem z drugiej ${ }^{109}$. Przenosząc to na grunt współczesnej teologii religii można

108 Zob. H. WALDENFEls, Absolutheitsanspruch des Christentums, w: LThK ${ }^{3}$ (Sonderausgabe 2006), t. I, 80-82.

109 Por. R. Bernhardt, Der Absolutheitsanspruch des Christentums, 164. Nasuwa się tutaj wyraźna analogia do G.E. Lessinga, który rozróżniał między uwarunkowaną historycznie wiarą Kościoła a czystą świadomością religijną, przyznając tej ostatniej charakter absolutny (por. tamże). 
by rzec: Tylko Bóg jest rzeczywistością absolutną; żadna religia - nawet chrześcijaństwo - nie może pretendować do iście boskiej absolutności. Pozostaje ona rzeczywistością relacyjną, skierowaną ku swej eschatologicznej pełni, która nigdy nie będzie adekwatnie objawiona w historii ${ }^{110}$.

Druga uwaga wiąże się z pierwszą i dotyczy zbawczego charakteru religii. Barth w sposób jednoznaczny wskazuje na fakt, iż każda religia, również chrześcijaństwo, potrzebuje nieustannego nawrócenia i oczyszczenia. Jej główne niebezpieczeństwo polega na zamknięciu się na działanie Ducha Świętego, zamknięciu się w literze świętej Księgi, literze Prawa, świętej Liturgii bądź Tradycji, które przy odpowiedniej interpretacji usprawiedliwić mogą nawet akty przemocy i terroru. Krytyka religii dokonana przez szwajcarskiego teologa wskazuje na podstawową prawdę, niekiedy przez członków religii zapominaną: „to nie religie zbawiają, lecz Bóg. Ludzie mogą się zbawić w religii i przez religię, bo tam doświadczyć mogą zbawczej łaski Jezusa Chrystusa. Ale nie zbawiają się dzięki religii, w sensie że religia stanie się przyczyną sprawczą zbawienia" "111. Gdyby tak było, mielibyśmy do czynienia $\mathrm{z}$ autosoteriologią, która sprzeczna jest z samą istotą chrześcijaństwa. Sięgając do kategorii scholastycznych można by powiedzieć, iż religie mogą stanowić przyczynę instrumentalną zbawienia (causa instrumentalis), co z kolei wskazywałoby na ich „sakramentalny” charakter ${ }^{112}$. Tak czy inaczej, ponieważ religia jest wypadkową działania Boga i człowieka, oraz ponieważ człowiek może być zarówno świętym, jak i grzesznikiem, w każdą religię, z chrześcijaństwem włącznie, wpisana jest ta sama ambiwalencją. Dlatego religia nieustannie potrzebuje wewnętrznego nawrócenia i oczyszczenia. Tak też widział to papież Benedykt XVI, który podczas międzyreligijnego dnia refleksji, dialogu modlitwy o pokój i sprawiedliwość na świecie, 27 października 2011 r. w Asyżu, powiedział: „Jest zadaniem wszystkich, którzy ponoszą jakąkolwiek odpowiedzialność za wiarę chrześcijańską, nieustannie oczyszczać religię chrześcijan, poczynając od jej wewnętrznego centrum, aby - mimo ludzkiej słabości - była prawdziwie narzędziem pokoju w świecie"113. Słowa te można bez wątpienia odnieść do wszystkich religii, gdyż w każdej z nich oprócz elementów dobra, prawdy i świętości, obecne są elementy zła i zepsucia. Należy ponadto pamiętać, że chociaż Bóg mógł oświecać ludzi na różne sposoby, nie mamy nigdy pewności, czy te światła zostały właściwie przyjęte i zrozumiane przez tych, którzy je otrzymali; jedynie w Chrystusie mamy

${ }^{110}$ Por. C. Gefrré, Jedyność chrześcijaństwa a pluralizm religijny, Znak 8 (1996) 495, 25.

111 Z. KuBACKI, Kościól, religie i zbawienie, Kraków 2016, 619.

112 Szerzej na ten temat zob. K. KaŁuża, Jeden Pośrednik $i$ wiele pośrednictw. Teologia religii wobec zbawczych roszczeń religii pozachrześcijańskich, „Roczniki Teologii Fundamentalnej” 3 (2011) 58, 140-142.

113 Benedykt XVI, Wszyscy jesteśmy odpowiedzialni za sprawy pokoju, Dzień refleksji, dialogu modlitwy o pokój i sprawiedliwość na świecie, 27 października 2011 r. w Asyżu; cyt. za: Z. KuBACKI, Kościót, religie i zbawienie, 620 . 
gwarancję przyjęcia woli Ojca. Taki też jest ostateczny wydźwięk chrystocentryzmu Bartha, który zgodnie ze świadectwem całego Nowego Testamentu powinien stanowić znak rozpoznawczy każdej autentycznie chrześcijańskiej teologii, w tym również teologii religii niechrześcijańskich.

\section{Bibliografia}

Balthasar H.U. von, Gott redet als Mensch, w: Tenże, Verbum caro, Einsiedeln 1960.

Balthasar H.U. von, Karl Barth. Darstellung und Deutung seiner Theologie, Köln $1962^{2}$.

BARTH K., Das Christentum und die Religionen, „Junge Kirche” 24 (1963), S. 436-438.

Barth K., Das Wort Gottes als Aufgabe der Theologie, w: K.-J. Kuschel (red.), Lust an der Erkenntnis: Die Theologie des 20. Jahrhunderts. Ein Lesebuch, München 1994, s. 69-86.

BARTH K., Der Römerbrief (1919), Bern 1919.

BARTH K., Der Römerbrief (1922), Zollikon - Zürich $1967^{10}$.

B ARTн K., Die christliche Dogmatik im Entwurf, t. I: Die Lehre vom Worte Gottes, München 1927.

Barth K., Die Kirchliche Dogmatik, München 1932-1937.

BARTH K., Die protestantische Theologie im 19. Jahrhundert, Zürich 1947.

BARTH K., Von der Paradoxie des ,positiven Paradoxes”. Antworten und fragen an Paul Tillich, ,Theologische Blätter” 2 (1923), s. 287-296.

Benktson B.E., Christus und die Religion. Der Religionsbegriff bei Barth, Bonhoeffer und Tillich, Stuttgart 1967.

Bernhardt R., Der Absolutheitsanspruch des Christentums. Von der Aufklärung bis zur Pluralistischen Religionstheologie, Gütersloh 1990.

Bronk A., Nauka wobec religii, Lublin 1996.

BrunNer E., Der neue Barth. Bemerkungen zu Karl Barths Lehre vom Menschen, „Zeitschrift für Theologie und Kirche” 48 (1951), s. 89-100.

EIcher P., Offenbarung. Prinzip neuzeitlicher Theologie, München 1977.

FrIEs H., Absolutheitsanspruch des Christentums, w: LThK ${ }^{2}$, t. I, s. 71-74.

Fries H., Das Christentum und die Religionen der Welt, w: K. Forster (red.), Das Christentum und die Weltreligionen, Würzburg 1965, s. 13-36.

GeFré́ C., Jedyność chrześcijaństwa a pluralizm religijny, „Znak” 8 (1996) 495, s. 14-27.

Grass H., Theologischer Liberalismus, w: RGG IV, Tübingen 1960³, s. 353-354. 
HeCKer K., Liberalismus und liberale Theologie, w: SM III, Freiburg 1969, s. 227-234.

Hessen J., Der Absolutheitsanspruch des Christentums. Eine religionsphilosophische Untersuchung, München - Basel 1963.

JASKóŁa P., Ku jedności w Chrystusie. Wybrane zagadnienia z problematyki ekumenicznej i dogmatycznej, Opole 2016.

JÜNgel E., Gott als Geheimnis der Welt. Zur Begründung der Theologie des Gekreuzigten im Streit zwischen Theismus und Atheismus, Tübingen 1978.

Kaluża K., Jeden Pośrednik $i$ wiele pośrednictw. Teologia religii wobec zbawczych roszczeń religii pozachrześcijańskich, „Roczniki Teologii Fundamentalnej" 3 (2011) 58, s. 117-149.

Kraus G., Gotteserkenntnis ohne Offenbarung und Glaube? Natürliche Theologie als ökumenisches Problem, Paderborn 1986.

Kubacki Z., Kościól, religie i zbawienie, Kraków 2016.

KüNG H., Existiert Gott? Antwort auf die Gottesfrage der Neuzeit, München $2004^{3}$.

LEDWOŃ I.S., , ,.. i nie ma w żadnym innym zbawienia”. Wyjątkowy charakter chrześcijaństwa w teologii posoborowej, Lublin 2006.

Marsch W.D., „, Gerechtigkeit im Tal des Todes”. Christlicher Glaube und politische Vernunft im Denken Karl Barths, w: W. Dantine, K. LÜTHI (red.), Theologie zwischen Gestern und Morgen, München 1968, s. 167-191.

Moltmann J., Bóg w stworzeniu, thum. Z. Danielewicz, Kraków 1995.

Niles D.T., Karl Barth - A personal Memory, „The South East Asia Journal of Theology" 11 (1969), s. 10-11.

Nossol A., Dialektyczna teologia, w: EK, t. III, kol. 1254-1255.

Rusecki, Objawienie Boże podstawa religii, w: G. DzIEwUlski (red.), Teologia religii. Chrześcijański punkt widzenia, Łódź - Kraków 2007, s. 157-182.

Schmidt-Leukel P., Gott ohne Grenzen. Eine christliche und pluralistische Theologie der Religionen, Gütersloh 2005.

Schmidt-Leukel P., Theologie der Religionen. Probleme, Optionen, Argumente, Frankfurt am M. 1997.

Smith W.C., Idolatry: In Comparative Perspective, w: J. Hick, P. KNitTer (red.), The Myth of Christian Uniqueness, Maryknoll 1987, s. 69-88.

ThiLs G., Problemy teologii religii niechrześcijańskich, tłum. J. Kowalczyk, Warszawa 1975.

Waldenfels H., Absolutheitsanspruch des Christentums, w: W KASPER I IN. (red.), Lexikon für Theologie und Kirche, Freiburg im Br. (Sonderausgabe) 2006', t. I, s. 80-82.

Werbick J., Den Glauben verantworten. Eine Fundamentaltheologie, Freiburg im Br. $2010^{4}$. 